\title{
Jamie Carreón Piñera
}

\section{Cinema Fantasma's}

\section{Extraordinary}

\section{Creatures.}

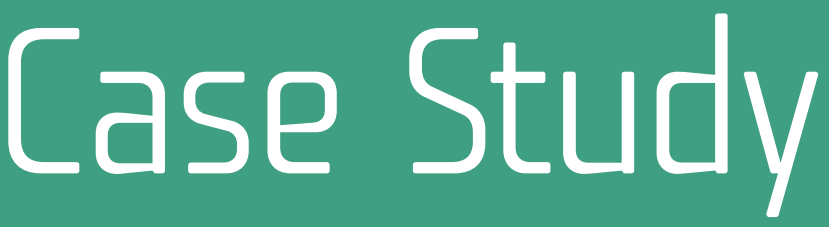




\section{Cinema Fantasma's Extraordinary}

\section{Creatures. A Case Study}

Jamie Carreón Piñera (0000-0002-3356-9055)

Startup Founding Partner and Business Innovation and Design Consultant, Mexico. jay@jasicapi.com

Fecha de recepción | 29 de mayo de 2020 | Fecha de aceptación | 3 de diciembre de 2020

\section{Abstract}

This article describes the case of Cinema Fantasma, a Mexican Stop Motion animation studio. It presents the process by which this firm designed and matured its business model, its creative process, as well as its current methods of creation and production, prop and character development. The research for this case study was made through the use of personal interviews with the founders and past employees; fieldwork and research. The main findings of this case study are as follows. There are several ways of achieving success, economic success is not always the most important one. The most important thing to achieve success is to focus on your passion and vision, then the story will follow. Success needs some luck and a lot of hard work. Having an agile methodology, such as SCRUM, and a multidisciplinary team allows the studio the flexibility to adapt to change and the project's needs.

Keywords $\mid$ Animation Studio, Film Process, Film Festivals, Stop Motion, Mexican Cinematography. 


\section{Caso de estudio: Criaturas extraordinarias de Cinema Fantasma}

\section{Resumen}

Este artículo describe el caso de Cinema Fantasma, un estudio mexicano de animación Stop Motion. Presenta el proceso mediante el cual esta firma diseñó y maduró su modelo de negocio, su proceso creativo así como sus métodos actuales de creación, producción, utilería y desarrollo del personaje. La investigación se realizó mediante el uso de entrevistas personales con los fundadores y ex empleados; trabajo de campo e investigación documental. Los principales hallazgos de este estudio de caso son los siguientes: hay varias formas de lograr el éxito, el éxito económico no siempre es lo más importante. Lo fundamental para lograr el éxito es concentrarse en su pasión y visión, luego seguirá la historia. El éxito necesita algo de suerte y mucho trabajo duro. Tener una metodología ágil como SCRUM y un equipo multidisciplinario que le permite al estudio la flexibilidad de adaptarse al cambio y las necesidades del proyecto.

Palabras Clave | Estudio de animación, Proceso cinematográfico, Festivales de cine, Stop Motion, Cinematografía mexicana.

\section{Copyright}

Centro de Diseño y Comunicación, S.C.@ 2021. Este es un artículo de acceso abierto distribuido según los términos de la Licencia de Atribución de Creative Commons (CC BY-NC-ND 4.0), que permite la descarga, el uso y la distribución en cualquier medio, sin propósitos comerciales y sin derivadas, siempre que se acredite al autor original y la fuente. 


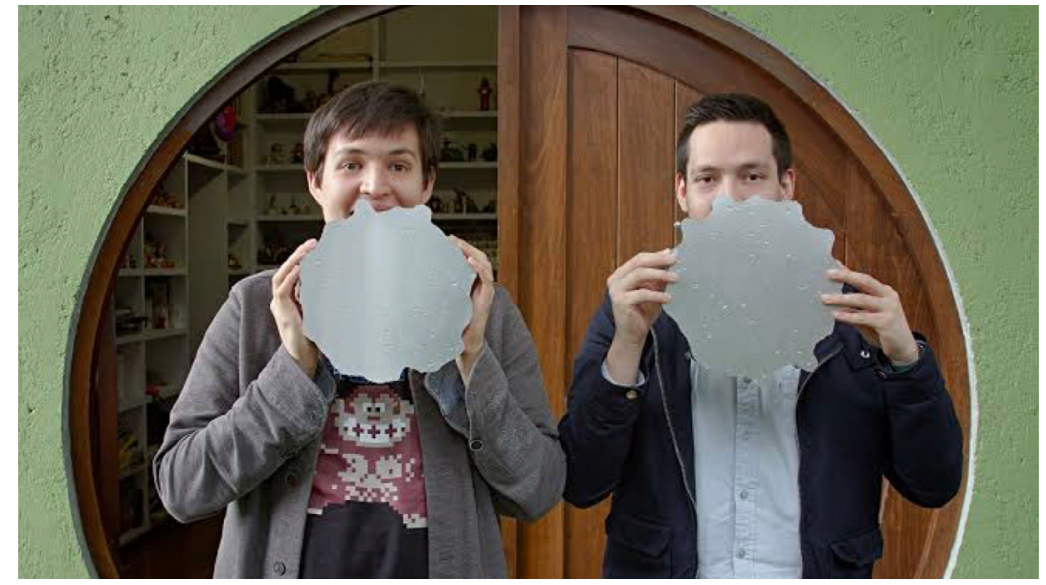

Image 1. Arturo (Vonno) and Rodolfo (Roy) Ambriz. Source: Retrieved from Cinema Fantasma Personal Archive.

\section{Introduction}

Cinema Fantasma is an example of a Mexican animation, film, and art studio that breaks ground and makes history, serving as an example of a successful family-owned studio that has won several international awards in the industry. This case study will begin by looking into the animation industry, especially its history in Mexico. After, the studio's history of how the Ambriz brothers (Image1), created the studio and what it is. Cinema Fantasma focuses on creating Stop Motion animation projects, and taking a look into what Stop Motion is and what their animation method is.

Being a creative organization there should be a creative process in place, it is a fundamental element in any project creation and the studios inspirations not only in their aesthetics moreover in their companies values and what they would like to grow into.

An important part of any company is the workforce and Cinema Fantasma could not be the exception. It is important to look into how the company has managed to retain their talent, some of them have been in the team since the early stages of the studio. How a multidisciplinary team gives the studio the flexibility to adapt to the project's needs. In addition to the organizations chart works in a horizontal format and how it is divided by stages every project goes through, direction being on top not only to supervise the team but more important to generate new business. 
SCRUM is one of the latest trends in project management and Cinema Fantasma found it beneficial. The paper looks into what the SCRUM methodology is and how the studio applies it. This paper looks into the projects the studio has been doing since its early stages and what it is working nowadays. No new company starts without challenges, Cinema Fantasma is no exception. Looking at the others' challenges and how they addressed them could be a source of inspiration even in other industries. direction being on top not only to supervise the team but more important to generate new business.

SCRUM is one of the latest trends in project management and Cinema Fantasma found it beneficial. The paper looks into what the SCRUM methodology is and how the studio applies it. This paper looks into the projects the studio has been doing since its early stages and what it is working nowadays. No new company starts without challenges, Cinema Fantasma is no exception. Looking at the others' challenges and how they addressed them could be a source of inspiration even in other industries.

\section{Film Animation in Mexico}

Although animation in Mexico has its history, it is a scarcely studied mode of expression. The first news of an animated projection was on August 14, 1907 in El Entreacto in Mexico City, they showcased Portrait animated by the cinematograph (Ángeles, 2013). According to Carlos Sandoval Bennet, the interest of animated cinema arose with the arrival of black and white cartoon films: Oswald the Lucky Rabbit (Image 2), Mickey Mouse (Image 3), Felix the Cat (Image 4) and Mutt and Jeff (Image 5). Its success was due to the absurd situations that prevailed in these drawings, where the characters could violate any physical law in the funniest way (Núñez \& Ocampo, 1996). 


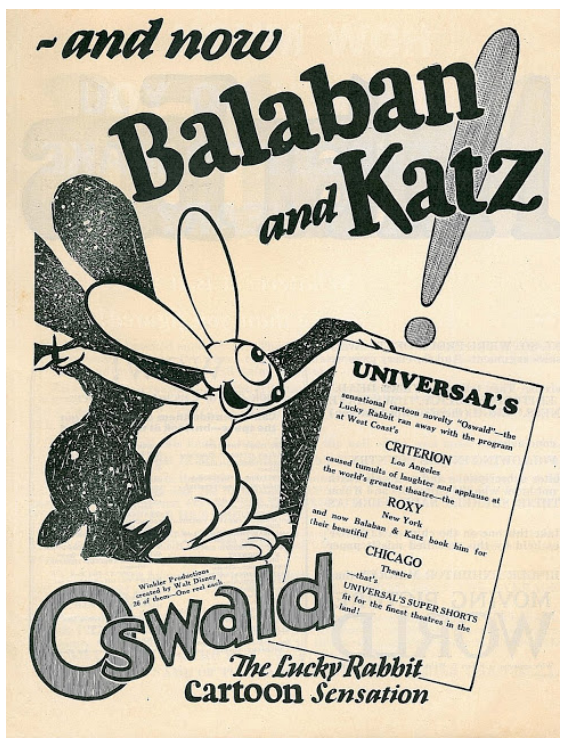

Image 2. Oswald the Lucky Rabbit.

Source: Retrieved from Mcelwee

(2010).

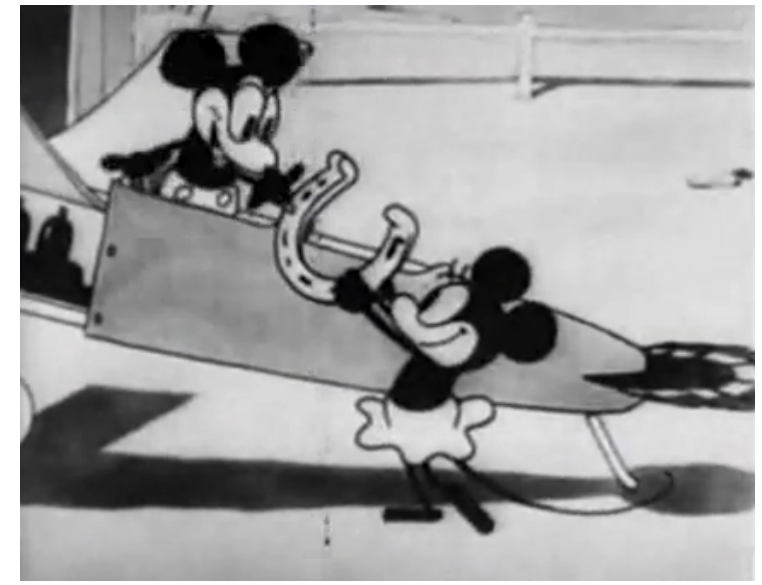

Image 3. Mickey Mouse.

Source: Retrieved from López (2013).

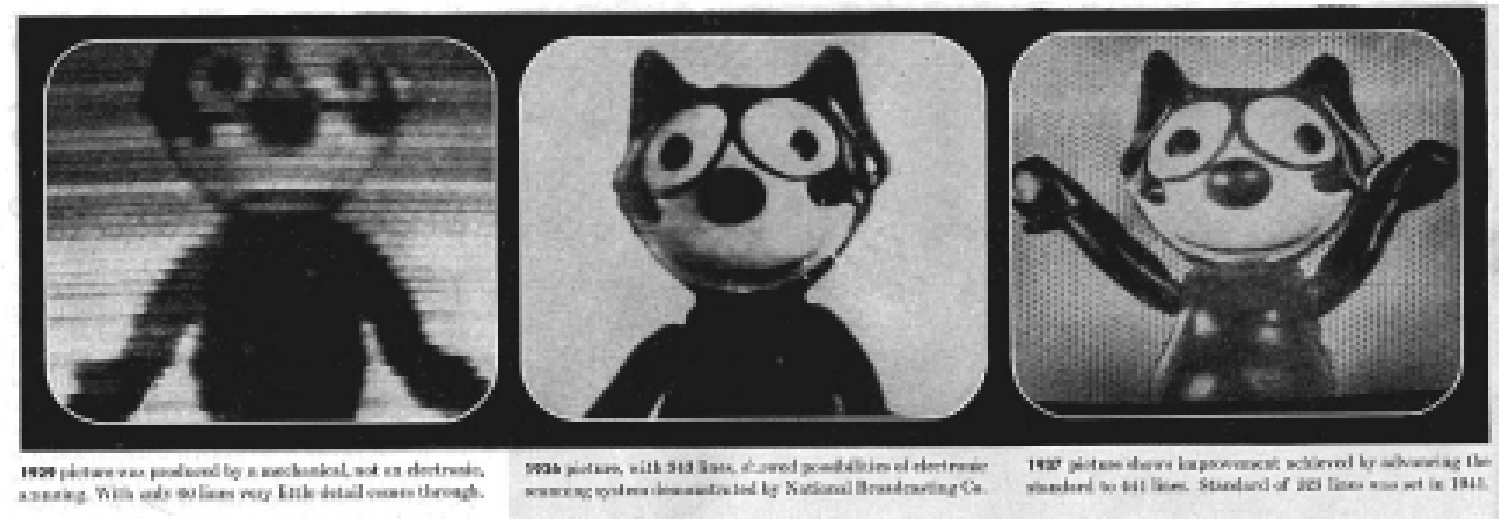

Image 4. Felix the Cat. Source: Retrieved from Anonymous (1944).

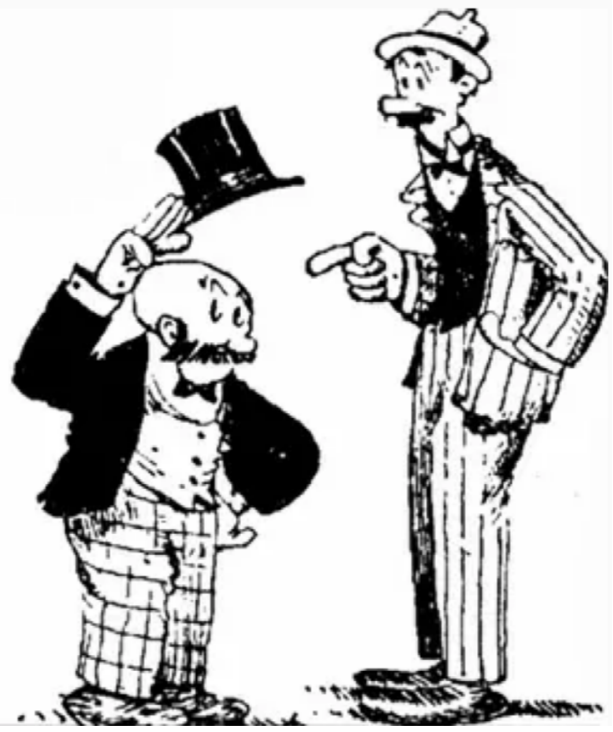


Animation in Mexico could be divided in fourth phases: the first: 1930-1944; the second: 1945-1973; the third: 1974-1993 and the fourth from 1994 to recent days (Rodríguez, 2007). The first phase were short films by private individuals that wanted to create films. The second phase were still short films but the first animation studios began appearing and a labor union with almost two hundred associates. It was not until the 70's that Mexicans began venturing into feature films with The Three Wise Kings as the first Mexican feature animation film, it began production in 1974 and exhibited in 1976. It narrated the story of the Wise Men in the Orient written by Rosario Castellanos (Image 6). However, it was not until 1984 that the first commercial success in the genere arrived with Katy the Caterpillar. It was a Mexican and Spanish production (Sector Cine, 2018).

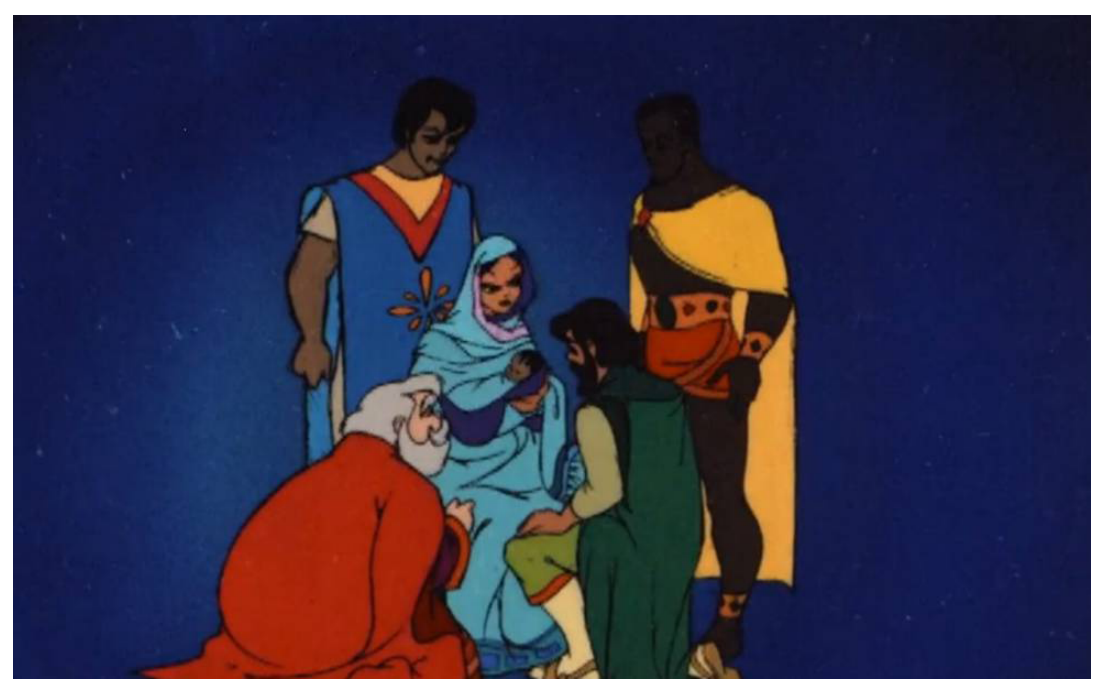

Image 6. Three wise Kings.

Source: Retrieved from

Sector Cine (2018).

Today (phase 4), independent animation in Mexico is the one that is truly achieving incredible things (Rodríguez, 2007). Such as Cinema Fantasma, an independent stop motion animation studio in Mexico. 


\section{Cinema Fantasma: Their Beginnings}

Cinema Fantasma was born in 2011; it started as the university dream of two brothers studying film at the university: Arturo (Vonno) and Rodolfo (Roy) Ambriz. They ideated the company during Vonno's last year, making a short film called Pluto and The Planets. It was his thesis project at Centro de diseño, cine y televisión (CENTRO) a school located in Mexico City. This short film explores the following premise: "A planet which is no longer a planet and a kid who is no longer a kid". Image 7 shows the official poster with which the film was screened.

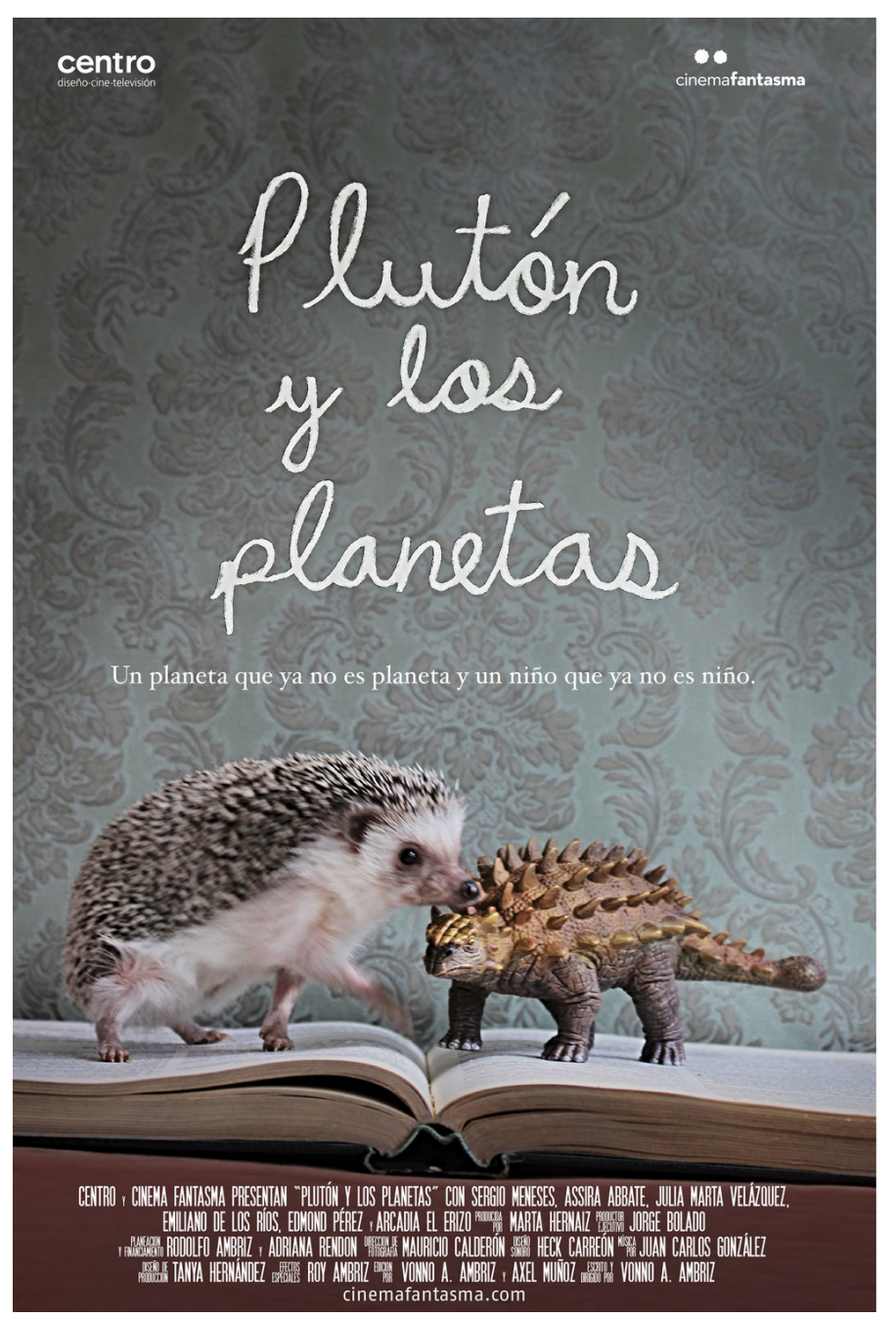


One of the main reasons to open the studio was to create the opportunity for creating and directing their own projects. Vonno mentioned in an interview to Forum the following:

We were interested in making fantastic animals, period films, and adventure films. I got nervous that studying film would not help me to direct films. It was when I told Roy and my parents that we should create a company where we could direct our own projects with monsters, fantasy, animation, and be able to do whatever we wanted (Forum México, n.d.).

So after graduating from university, Vonno took a workshop on Entrepreneurship, developing a business and got the stepping stones to create a company. In this context, he came up with the brand and registered the legal name Espacio Creativo Cinema Fantasma, S.A. de C.V. and everything became official. The logo is a playful child using a sheet as a ghost costume, using two drops of paint because what drives Cinema Fantasma is their creativity and handcrafts (Image 8). As Hector Carreon (Image 9), who is a friend and part of the beginnings of the studio and early stages of Revoltoso, remembers in an interview (Carreon, personal communication, 2020).

\section{•. \\ cinemafantasma}

animation, film and art studio
Image 8. Cinema Fantasma logo.

Source: Retrieved from Cinema

Fantasma (2021). 


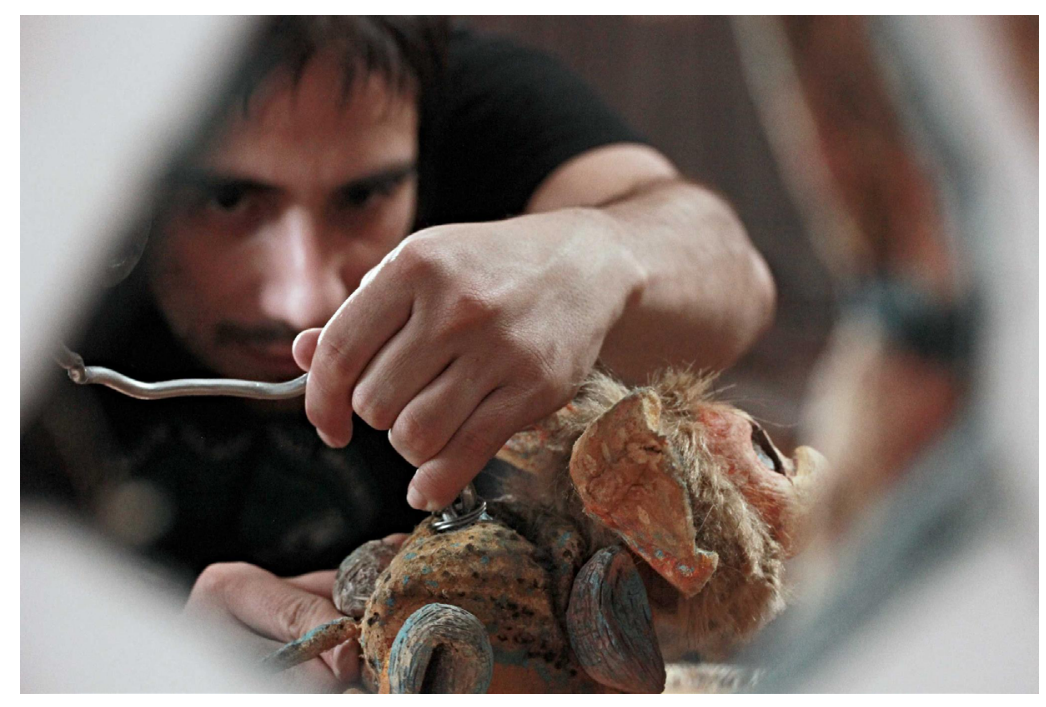

Image 9. Hector Carreon moving

Jabalito for a shot.

Source: Retrieved from Cinema

Fantasma (2013a).

Vonno and Roy find it fascinating that there are so many beliefs surrounding ghosts despite the lack of definitive scientific evidence, a phenomenon that, in their opinion, is repeated in art. Besides, ghosts are light projections, just like movies. The idea of creatures emerging at the cross point between those concepts was a great starting point for their identity. They mentioned Forum in an interview of all the possibilities a sheet costume gives kids and how this idea represents the core value for Cinema Fantasma: "You take a sheet, make two holes and that is enough to create a totally different character, you live another reality and this action represents what we want to do" (Image 10) (Forum México, n.d.).

Cinema's Fantasma mission is to create projects with quality and positive content. They are aware of their social responsibility because of their impact on children. In their own words: "Here we imagine [...] we are a friendly ghost, not one that scares [...]" (Ambriz, personal communication, 2020a). Looking to portray their Mexican heritage they implemented the slogan that seeks to portray like a local small business, like a plumbing service where they advertise as: here we fix pipes. Nonetheless, nowadays because their clients are becoming more international they felt like their name was too conceptual and felt the need to add the tagline animation, film and art studio to their logo (Ambriz, personal communication, 2019a). 


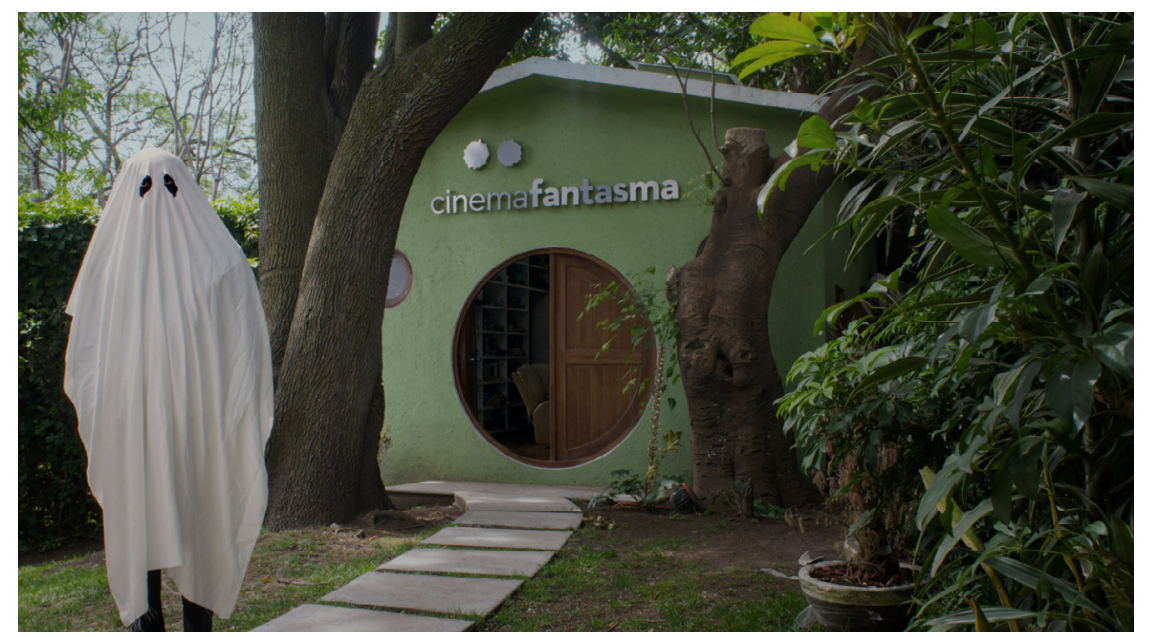

Image 10. The Friendly Ghost.

\section{What is Cinema Fantasma?}

Cinema Fantasma is a cinema, art and animation studio with a homey atmosphere. They even converted their family home into the studio. Focusing on creating mainly with stop motion animation. It is common to see Adriana, their mother and graphics professional, collaborating with them making the sets, props and puppets they will use for each production (Image 11) and their father working as a project manager.

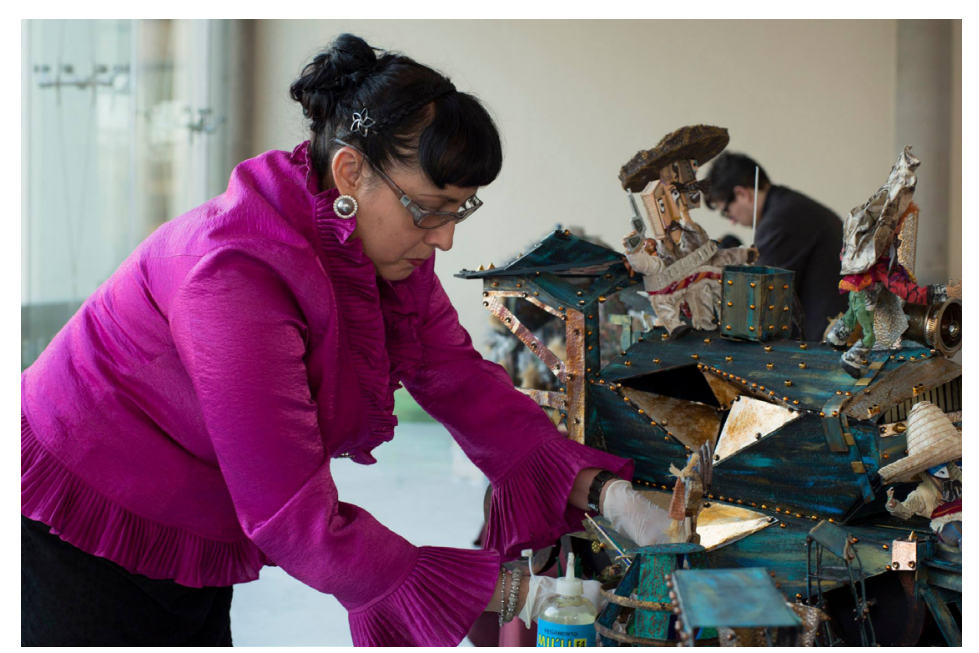




\section{About Stop Motion}

Stop motion (also called stop frame animation) is animation that is captured one frame at time, with physical objects that are moved between frames (Figure 12). When the sequence of images is played back rapidly it creates the illusion of movement. The basic process of animation involves taking a photograph of objects or characters, moving them slightly, and taking another photograph (Purves, 2010; DragonFrame, 2020). In a world dominated by computer images, alternative stop motion techniques like pixelation, time-lapse photography and down-shooting techniques combined with new technologies offer a new, tangible and exciting approach to animation (Gasek, 2012). Barry Purves provides a more romantic definition for the stop motion animators, they create a moving performance between frames without ever being seen themselves, creating the illusion of independent continuous movement. Stop motion combines the relatively modern world of animation with the ancient tradition of puppetry. Yet, it is not performed in real time, nor played in front of an audience and usually the operators are not seen (Purves, 2010).

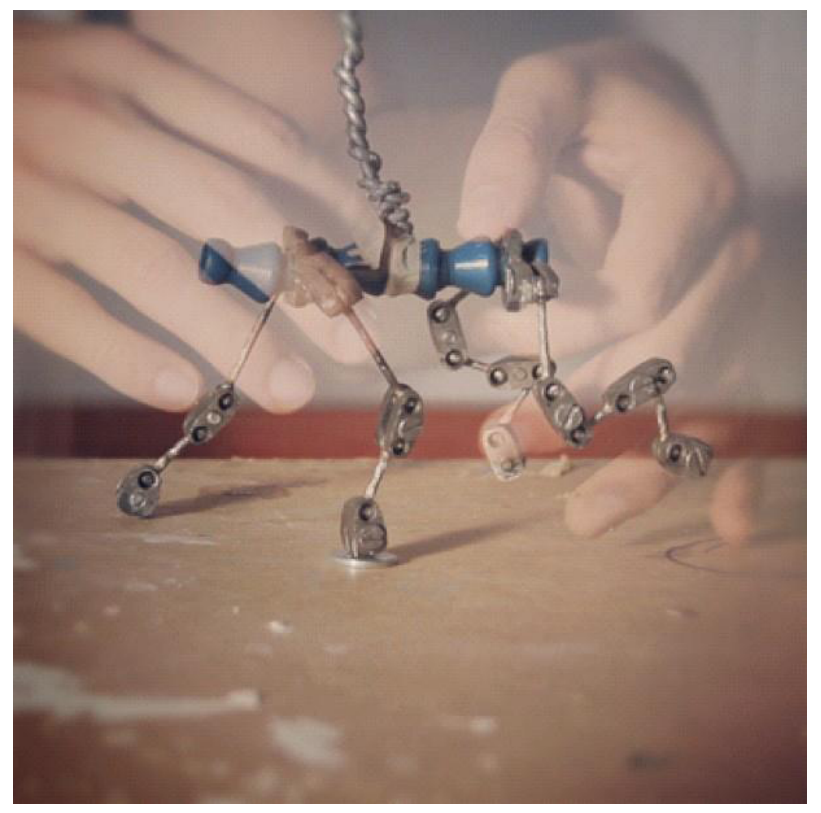


There has been increasing interest for utilizing the stop motion animation technique in Mexico. For example Cerulia by Sofia Carrillo (Image 13), which won best short film in 2018 in the Ariel, and Ana and Bruno by Carlos Carrera (Image 14) who also has been in several festivals around the world. (Rios, 2020)
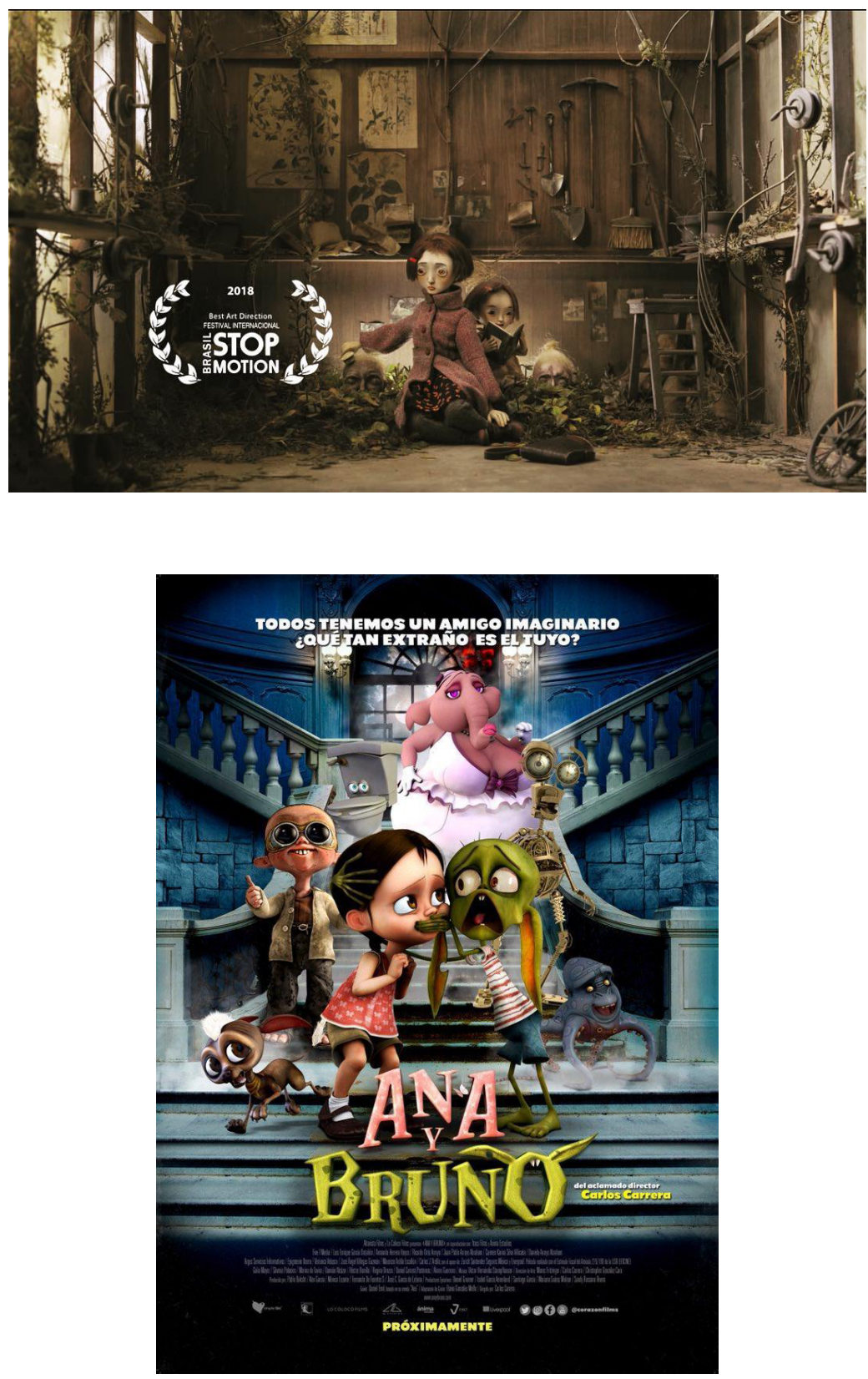

Image 13. Cerulia.

Source: Retrieved from Carrillo (2018). 
In an interview with LatAm cinema, Vonno explained their style:

We are fascinated by art and history. For Revoltoso we got inspired by cubism and the Mexican Revolution. Now we want to work with the medieval ages (when explaining the inspiration for the Ballad of the Phoenix). We are interested in deformed animals with weird proportions, the heraldic, castles, manuscripts illustrated by monks. The studio style will be present but with a cleaner and figurative look. (Garcia, 2016).

\section{The Cinema Fantasma Creative Process}

Their inspiration comes from the constant creativity they seek to continue creating and magic and history specially from animation movies (Image 15). As a studio they got inspired by the Studio Ghibli (Image 16) and Jim Henson² (Image 17).

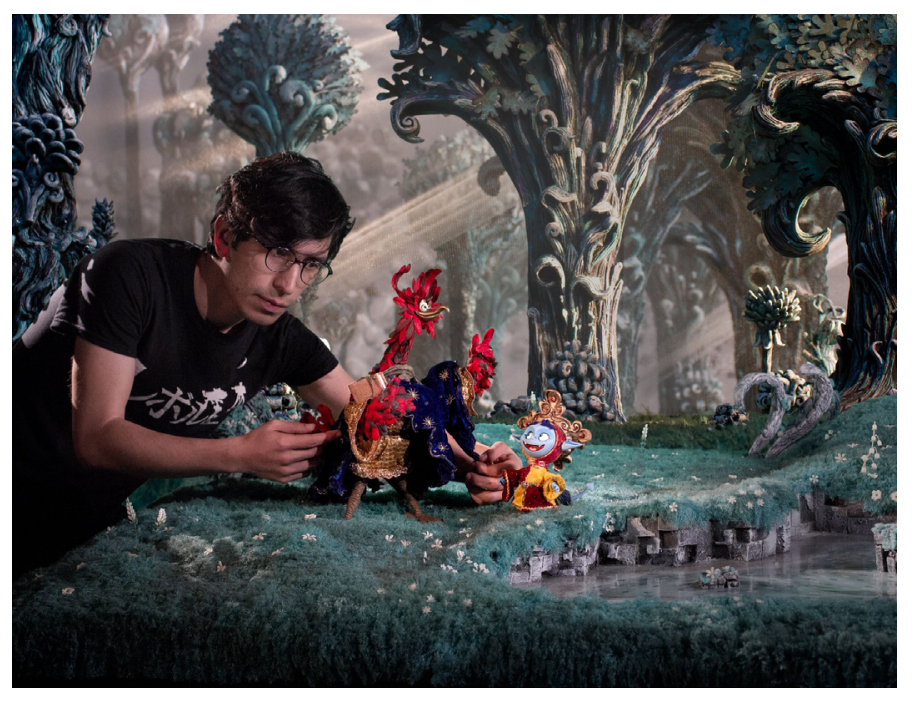

1 Studio Ghibli was created by Tokuma Shoten, who produced Nausicaä of the Valley of the Wind in 1985. Since then, the studio has been producing mainly animated films directed by Hayao Miyazaki and Isao Takahata. Ghibli is the hot air that blows in the Sahara Desert. A studio that does not produce anything other than original works that are extremely unique in the world of Japanese animation, (Studio Ghibli, 2017).

2 He was an American puppeteer and filmmaker, creator of the Muppets of television and motion pictures. He coined the term Muppets as a meld of marionettes and puppets. 

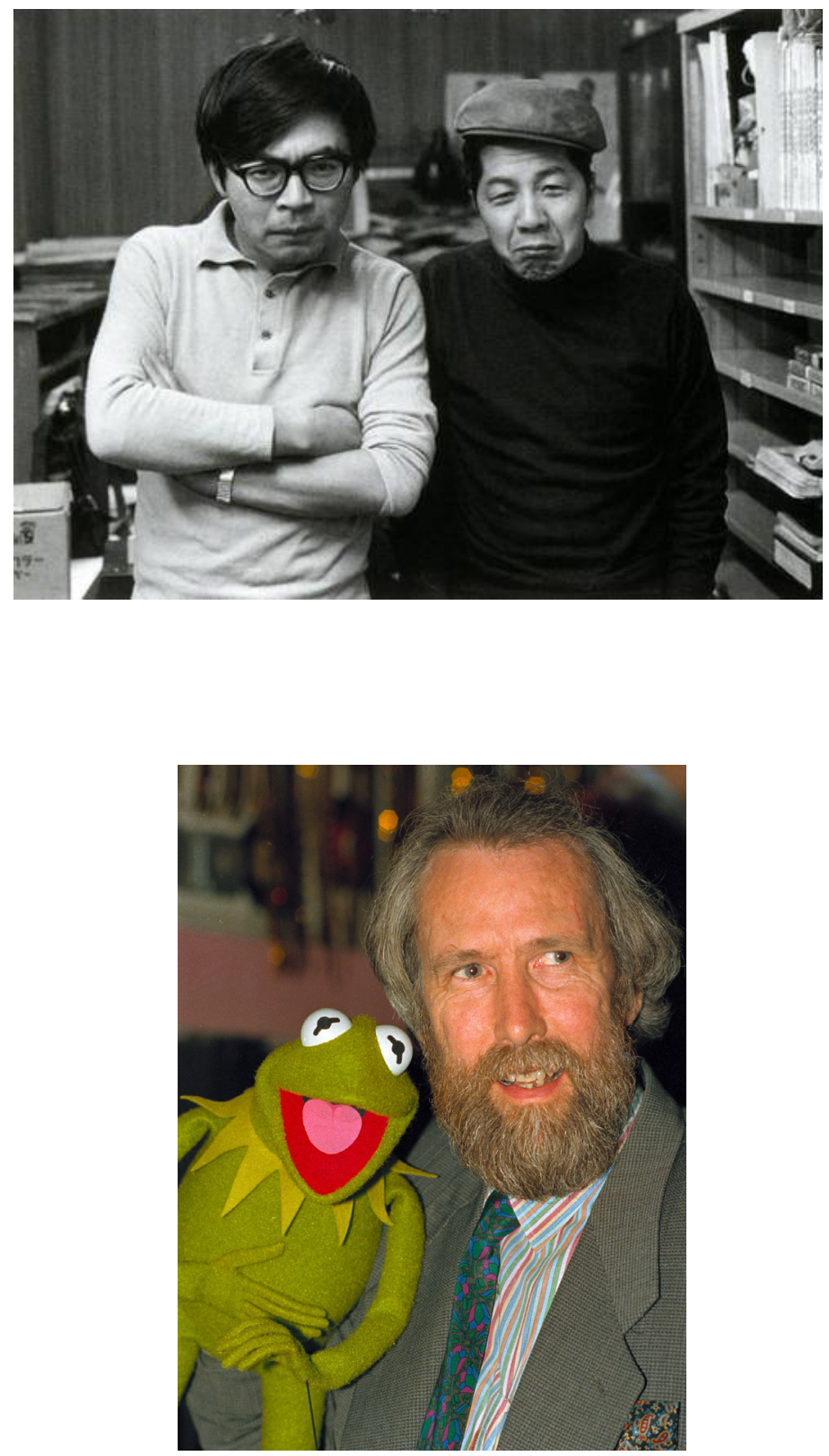

Image 16. Hayao Miyazaki e Isao Takahata, Studio Ghibli founders.

Source: Retrieved from Studio

Ghibli (2017).
Image 17. Jim Henson and Kermit the Frog. Source: Retrieved from Encyclopædia Britannica (2021)

From Studio Ghibli, Cinema Fantasma got inspired for the type of studio they wanted to be. They have never been worried to grow like a big studio, they seek to be a small to medium size studio. They determine the size by aumont of projects being developed at the same time, creating no more than two projects at the time. A place where all their productions will be created and directed in house. Productions being born from their inspiration and just focusing on getting from one project to another, never stop producing even when it takes several years previewing a production. 
Part of the revenue in the business model of this type of companies, in animation and film, is not only by the screening of the film but the memorabilia and merchandising (Image 18). Studios usually sell the rights of production to one or several companies. In the case of Studio Ghibli they do not sell the rights or outsource, the memorabilia and museum are part of the studio, such is the case for Cinema Fantasma.

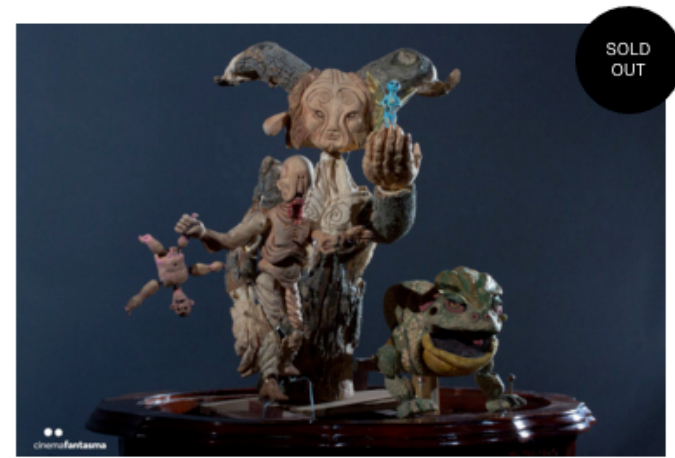

Vonno \& Roy Ambriz (Cinefantasma) "Labyrinthum Locum Dare Spei"

$\$ 6,500.00$
Image 18. Memorabilia sold by

Cinema Fantasma. ${ }^{3}$ Source:

Retrieved from Cinema Fantasma (2015a).

Jim Henson's Muppets are made of sculpted foam rubber, plastic, and various fabrics, the characters were either hand puppets or fully costumed persons (as in the case of Big Bird and Snuffleupagus). Except in certain movie sequences using special effects. (Britannica, 2020). Henson inspires Cinema Fantasma with the creation of the sculpted characters and also the concept of creating a fantastic mixture between stories for adults but at the same time noble, fun and kid friendly.

In order to define the company's value proposition, the founders decide in not doing formal market research, however keeping in mind world trends and what other studios are making. As an idea iteration they rather have conversations, 
especially with their crew. They applied Guillermo's del Toro idea development. Vonno mentioned the words of wisdom Guillermo del Toro 4 (Image 19) shared with them, that the studio has been applying ever since: "if you create something that you would have liked or would like to watch there will always be other people that will like it too" (Ambriz, personal communication, 2020a).

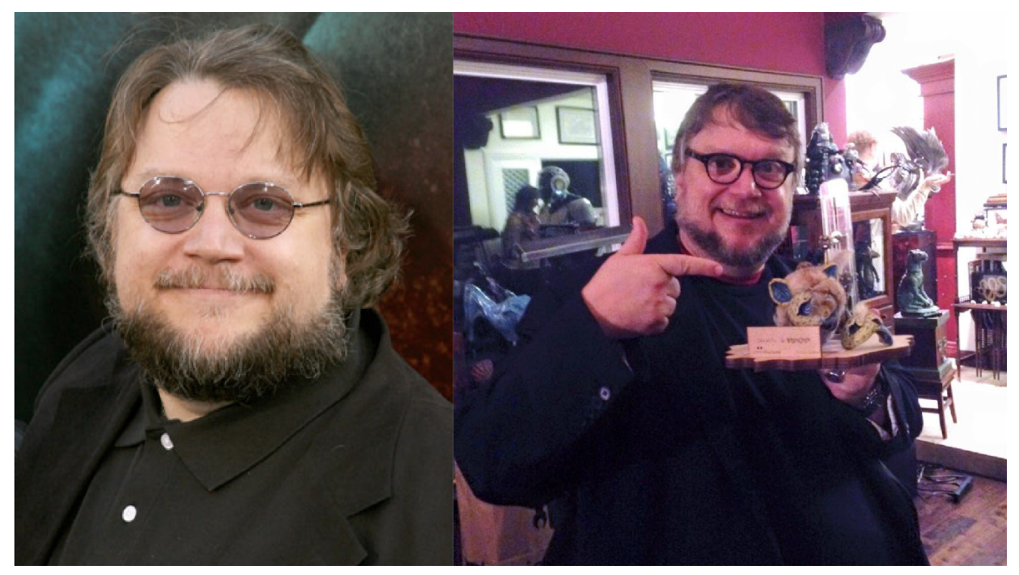

Image 19. Guillermo del Toro.

Source: Retrieved from IMDb

(2021) and Cinema Fantasma

(2016).

As for when writing the script they decided to apply Adam Elliot ${ }^{5}$ (Image 20) teachings. Drafts of a script should not be shown to more than six people because the more voices comment on it, the more contradictory feedback the work will receive. In addition, taking in account all the opinions could be complicated and can even lead to a radical change in the story with each treatment. This was a lesson they learned the hard way when in 2014 during the shooting of Revoltoso they realized not having a script was utilizing too many resources and time. They took a step back and worked on the story, improving their process (Image 21). 

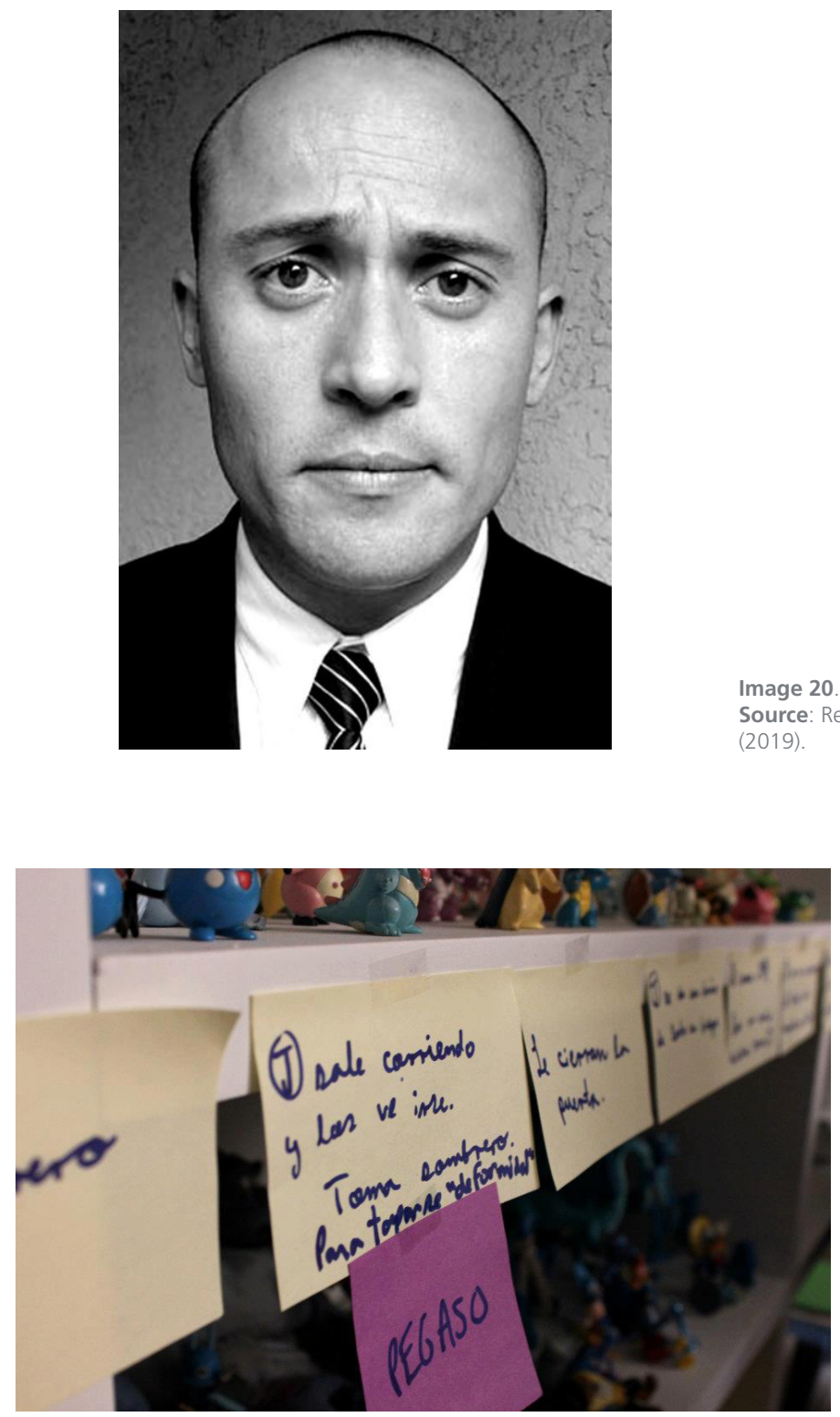

Image 21. Scene design for

Cinema Fantasma's success could also be attributed to its well-defined aesthetic, with handcraft processes which directs all its projects; a very solid work team that has strengthened their creative processes by professionalizing the way they work. Their aesthetics and creative concept have given the studio the confidence to not be afraid to carry out projects as they see fit. Considering their aesthetics as a combination of contemporary design, with cinematography and a childish, unique, rebellious and anarchic touch (Ambriz, personal communication, 2019b). They seek to create monsters, tell stories and talk about specific topics 
(Betancourt, 2016). Irene Melis (Image 22), Cinema Fantasma Photography Director, described their style in an interview for Women we love:

\section{[...] clients look for us because we have a unique style and that is what gets their} attention. We have references of what we like, search the way of making it unique and adapt (Image 23 and 24), sometimes they ask for lighter backgrounds or that the characters are not so weird but without losing the essence of what we like and are, this is something we always have clear, we are not doing something we do not like or that goes against our principles [...] (Rios, 2020).

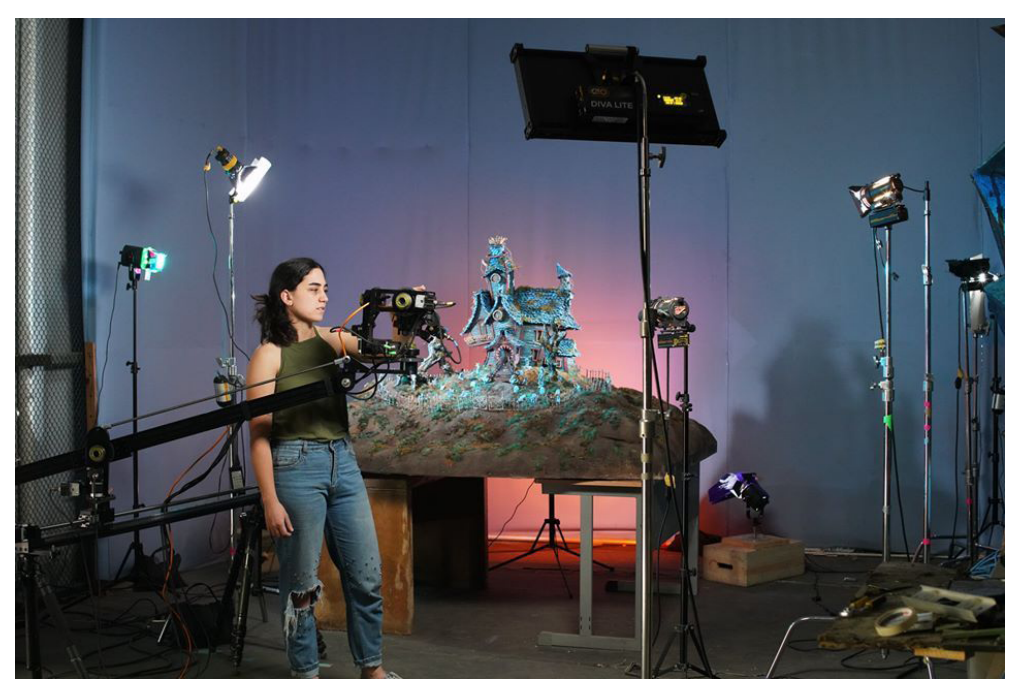

Image 22. Irene Melis animating Source: Retrieved from Rios (2020)

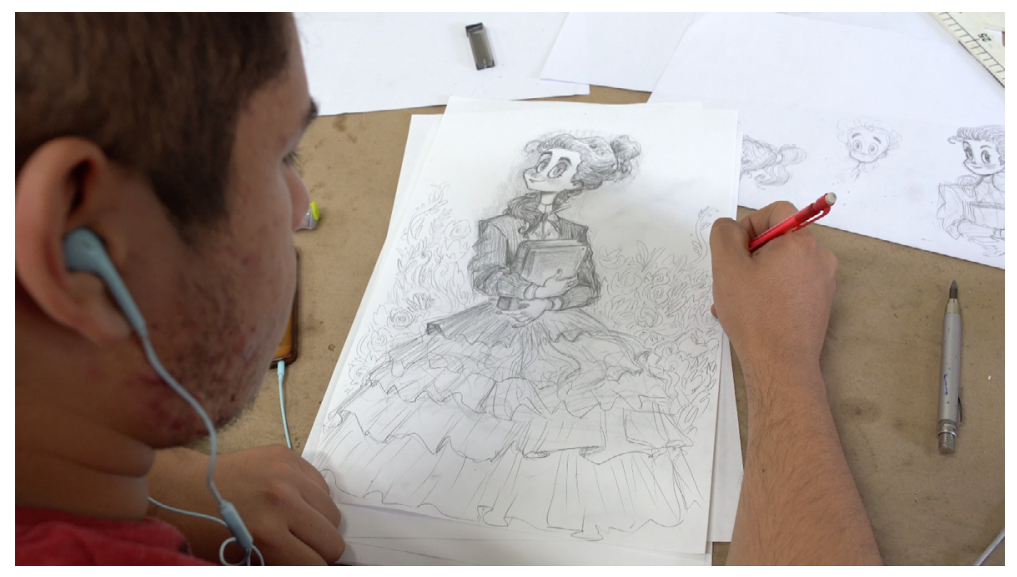




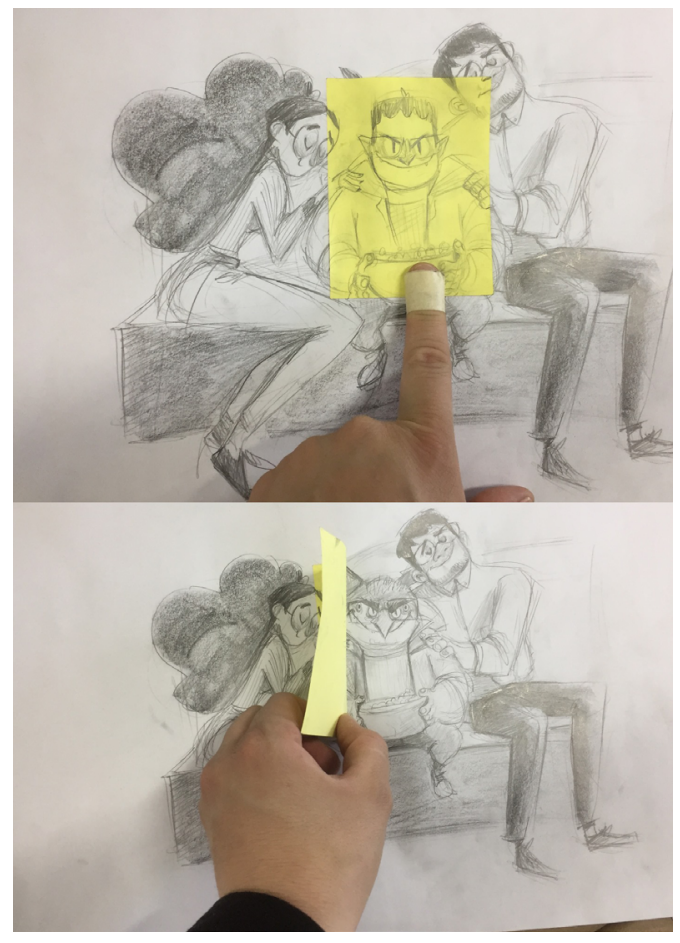

Image 24. Trying different options for the

character. Source: Retrieved from Cinema Fantasma (2019b).

Cinema Fantasma is considered a successful animation studio because they have been able to continue growing, even in uncertain times. The studio has continuously signed contracts with big name brands. Another measurement for their success is the festivals and awards won over time with several of their projects (Huntly, 2018).

\section{The Creative Process}

In the early days they would create the whole project to realize if the idea would work or not, the trial and error method. Their expertise has allowed them to realize if their ideas will work or not from the moment they are brainstorming. From their initial brainstorm they are already figuring out how the puppets will look; the feeling of the scenery; how they will do the shooting; the type of photography used and how they are going to post-produce. They are in constant communication, the team works in their special field, however, they are specialized in several areas therefore they are in constant rotation from one department to another. Believing in creating specific deliveries not departments.

Their process has made more efficient and effective shots. Reducing time per frame to one of the lowest times in the industry. For example shooting for the 
movie Corpse Bride (Image 25) by Tim Burton took a week for every two seconds (Rowe, 2005). In shooting Anomalisa (Image 26) directed and produced by Charlie Kaufman and Duke Johnson each animator shot two seconds per day (Paramount Pictures, 2015).
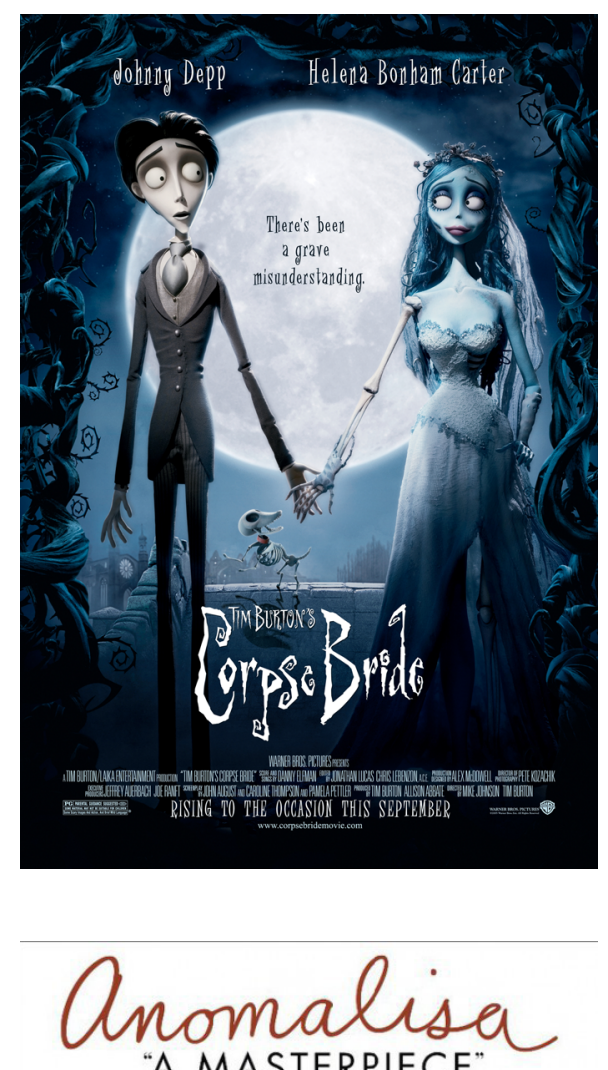

"A MASTERPIECE."

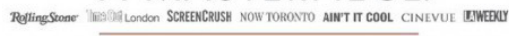
"A WONDERFUL MOVIE, A FUNNY MOVIE, A SAD MOVIE, A SHATTERR
MOVIE, A TRUE MOVIE, AN HONEST MOVIE, A BEAUTIFUL MOVIE AND AN ESSENTIAL MOVIE.
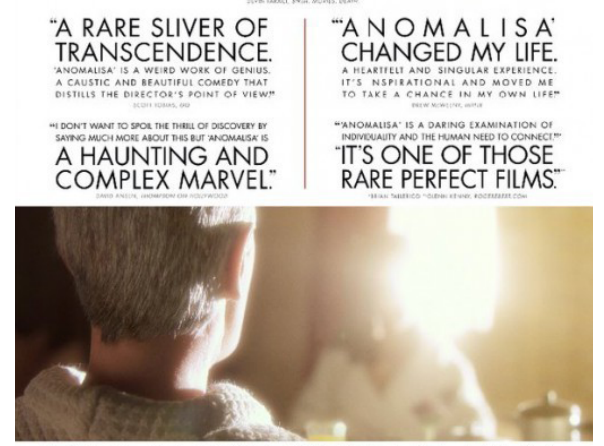

"THE MOST HUMAN FILM OF THE YEAR".

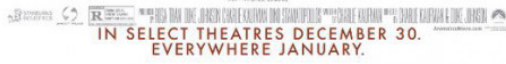

Image 25. Corpse Bride. Source: Retrieved from IMDb (2005). 
While shooting Isle of Dogs (Image 27) by Wes Anderson, the sushi scene that lasts forty five seconds took upto six months to shoot including the extent research of how to cut the ingredients properly (Átomo Network, 2020). Whereas the team can produce seven seconds per day getting to thirty five seconds a week (Ambriz, personal communication, 2021a). It is essential for the team that even though the animators are shooting in record time they do not sacrifice their spare time, overwork them or work extra time (Ambriz, personal communication, 2021b). The team believes they have reduced their shoot time cause there is no other way, their limited budget avoids wasting time in rethinking the shoots or reshooting scenes, which helps in reducing their time. Another reason for reducing their shooting time is having in mind the puppet design while writing the script.

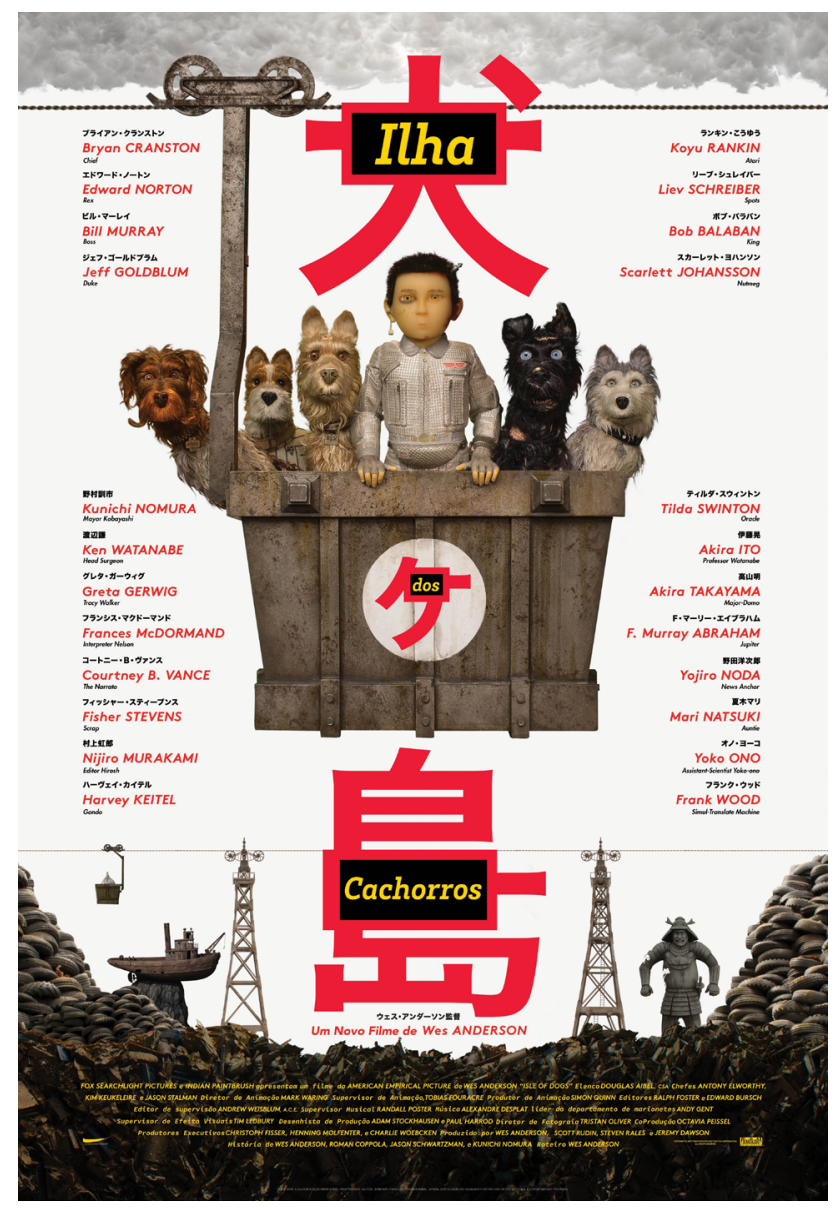


As Vonno mentions, if the character speaks the puppet needs to have their mouth designed for each movement (Images 28 and 29). Also it is easier to design, move and shoot scenes with muppets with human anthropomorphics (Images 30 and 31). In addition he mentioned, it is easier and faster to shoot scenes in green screen, like in (Image 32), the more elaborated the model the harder and time consuming the shooting will be (Images 33 and 34).

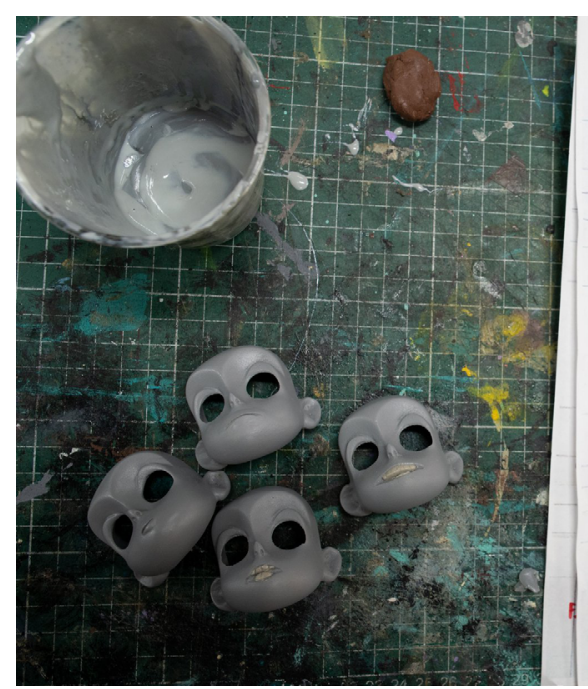

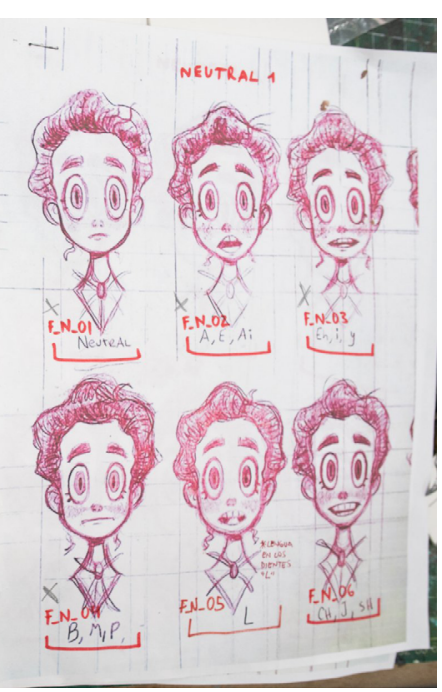

Image 28. Face expressions design Source: Retrieved from Cinema Fantasma (2019d).

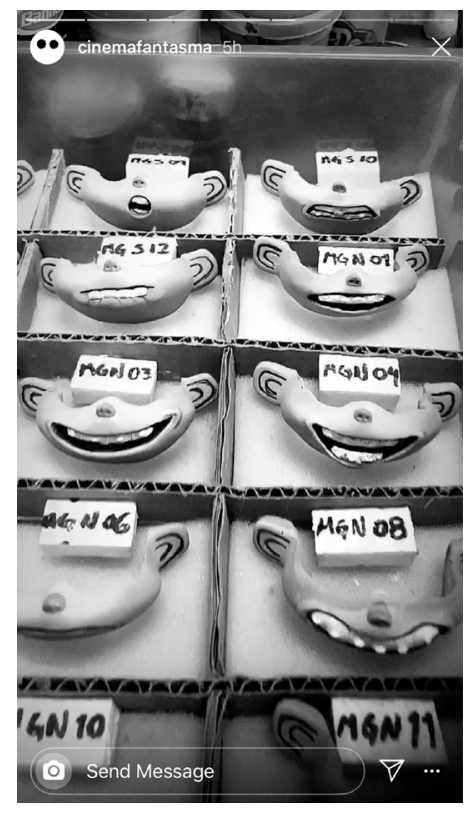




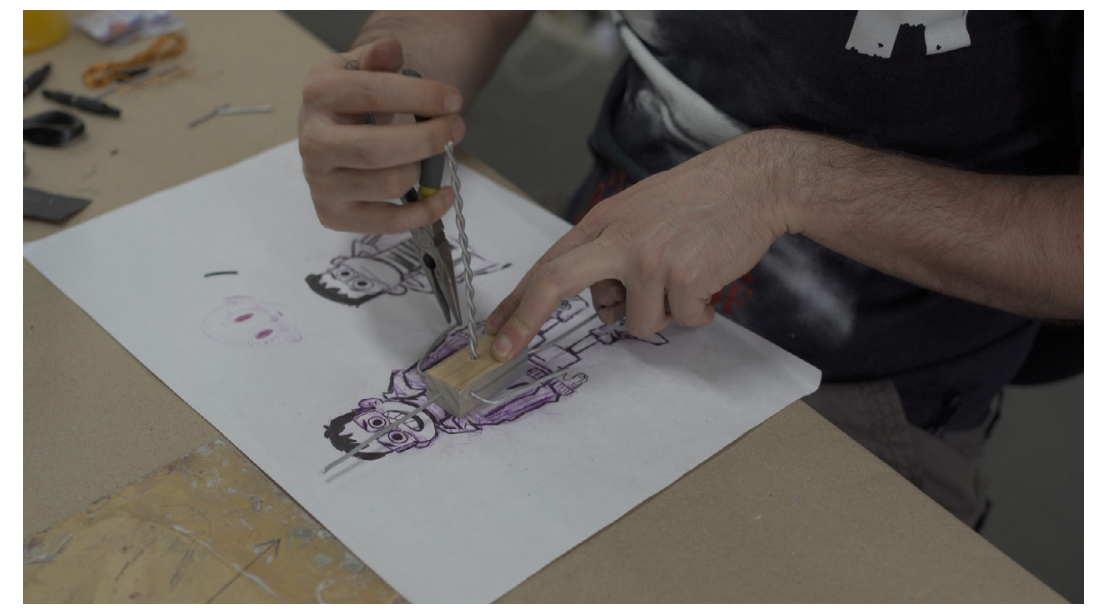

Image 30. Designing the body for the puppet. Source: Retrieved from Cinema Fantasma (2019c).

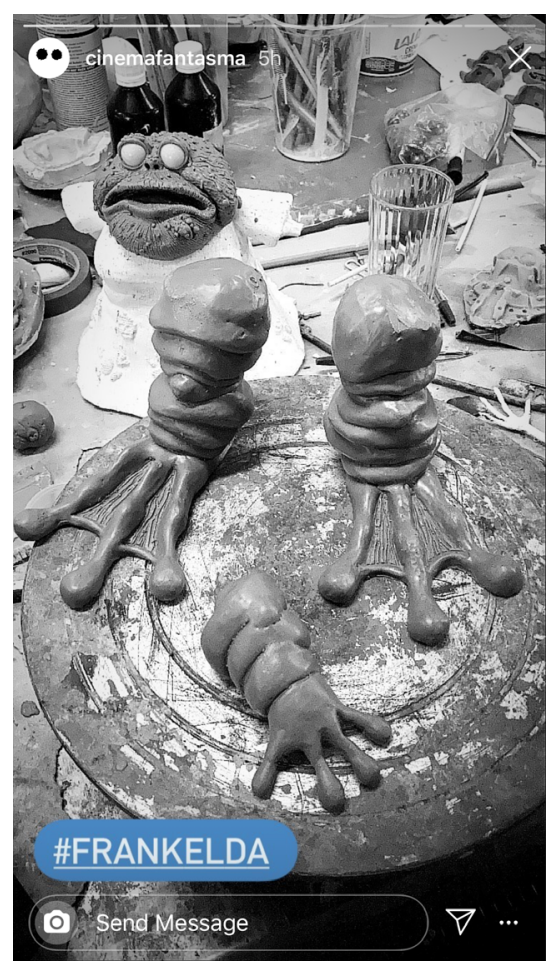

Image 31. Characters clay

modeling. Source: Retrieved

from Cinema Fantasma (2020b).

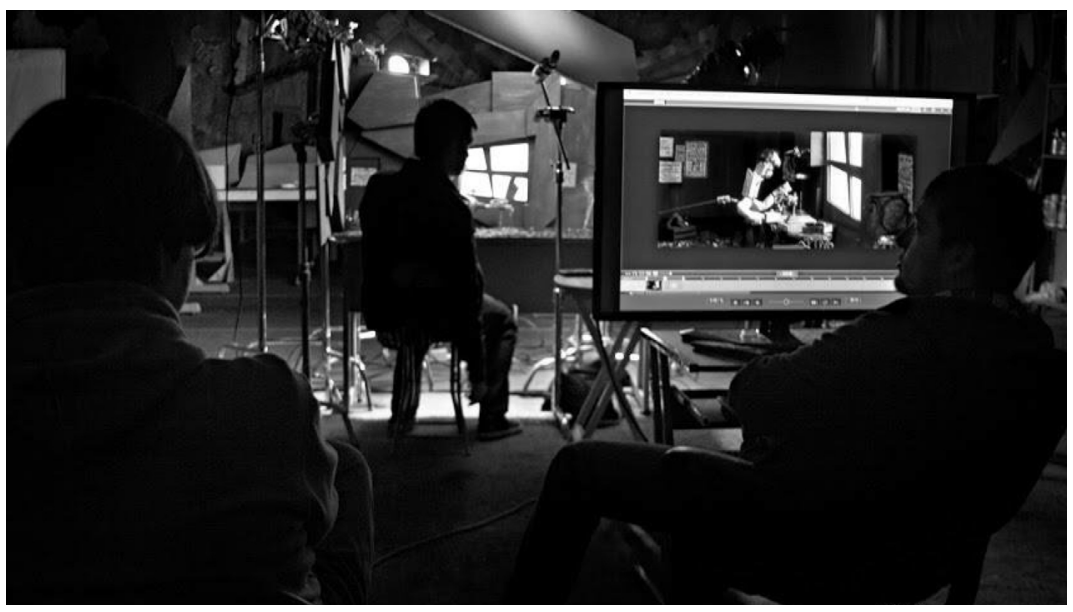




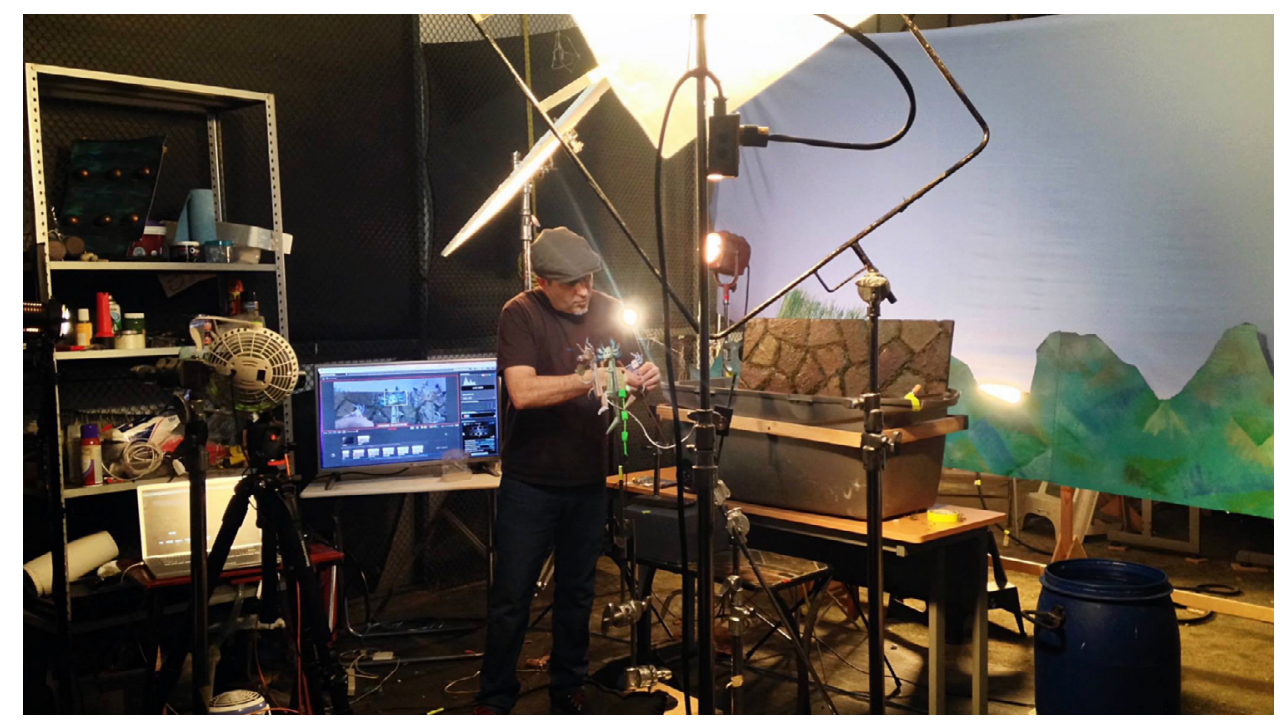

Image 33. Transition between takes. Source: Retrieved from Cinema Fantasma Personal Archive.

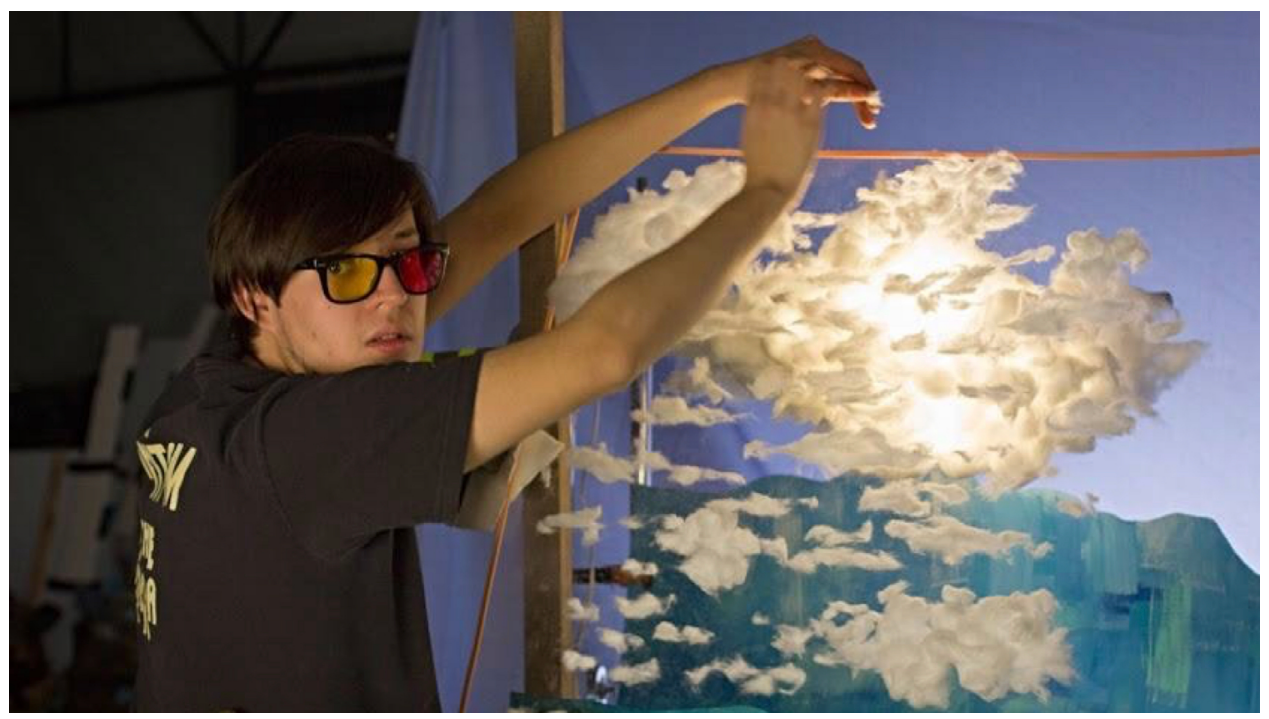

Image 34. Setting the scenery. Source: Retrieved from Cinema Fantasma Personal Archive.

After the pandemic by COVID-19 there has been limited access to the studio, no outside visitors. The team is currently working with safety measures in place, four teams are working simultaneously with black curtains dividing to control the lighting, look and feel of the scene (Image 35). 


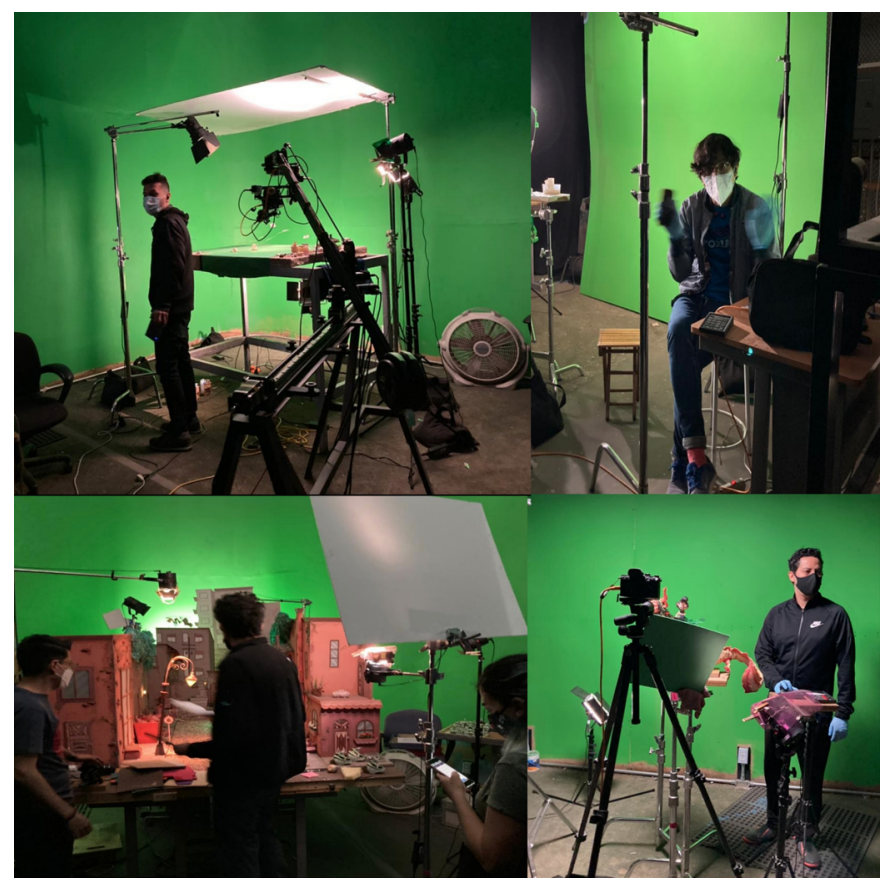

Image 35. The team worked in post-Covid 19 conditions, four scenes at the time. Source: Retrieved from Cinema

Fantasma Personal Archive.

For example in an interview with the El Universal newspaper Vonno described their inspirations for creating Frankelda:

[...] is inspired by Mary Shelley, who wrote Frankenstein and in a novel called Mathilda, the mixture of them gave the name [...] (Huerta, 2020).

As for the inspiration for the whole series he mentioned the following:

[...] The stories are a mixture of modernized fairy tales, mythological tales, Mexican legends, stories that we came up with, but they are all about children to whom something strange happens with a supernatural being we call The Secret Scares [...] (Huerta, 2020).

\section{Projects}

Table 1 portrays the main projects Cinema Fantasma has worked on so far. Image 36 is a time frame sketch for the projects. 

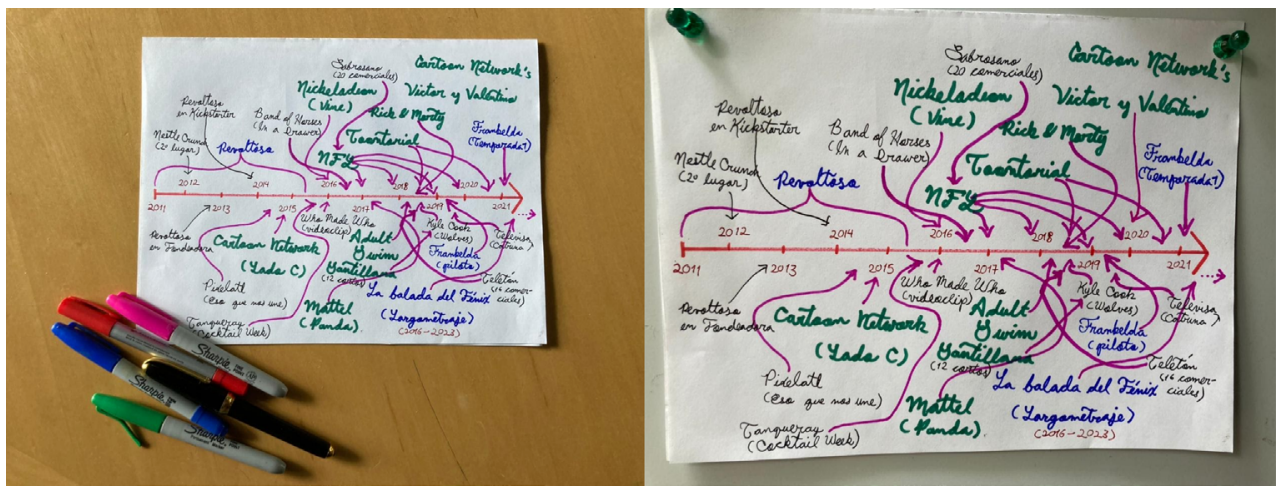

Image 36. Cinema's Fantasma

Timeline. Source: Retrieved from

Cinema Fantasma Personal Archive.

\section{Table 1. Cinema Fantasma Projects.}

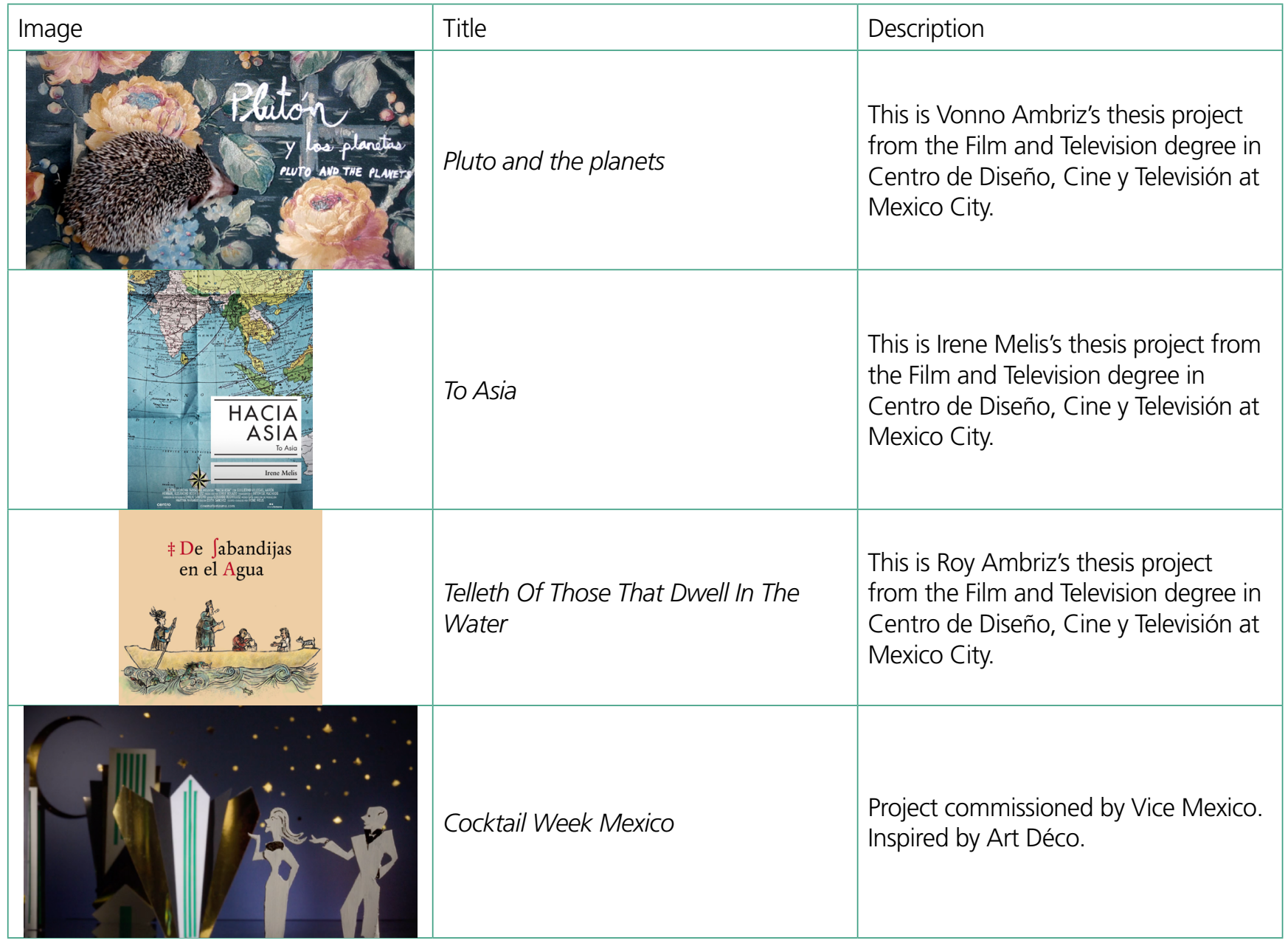




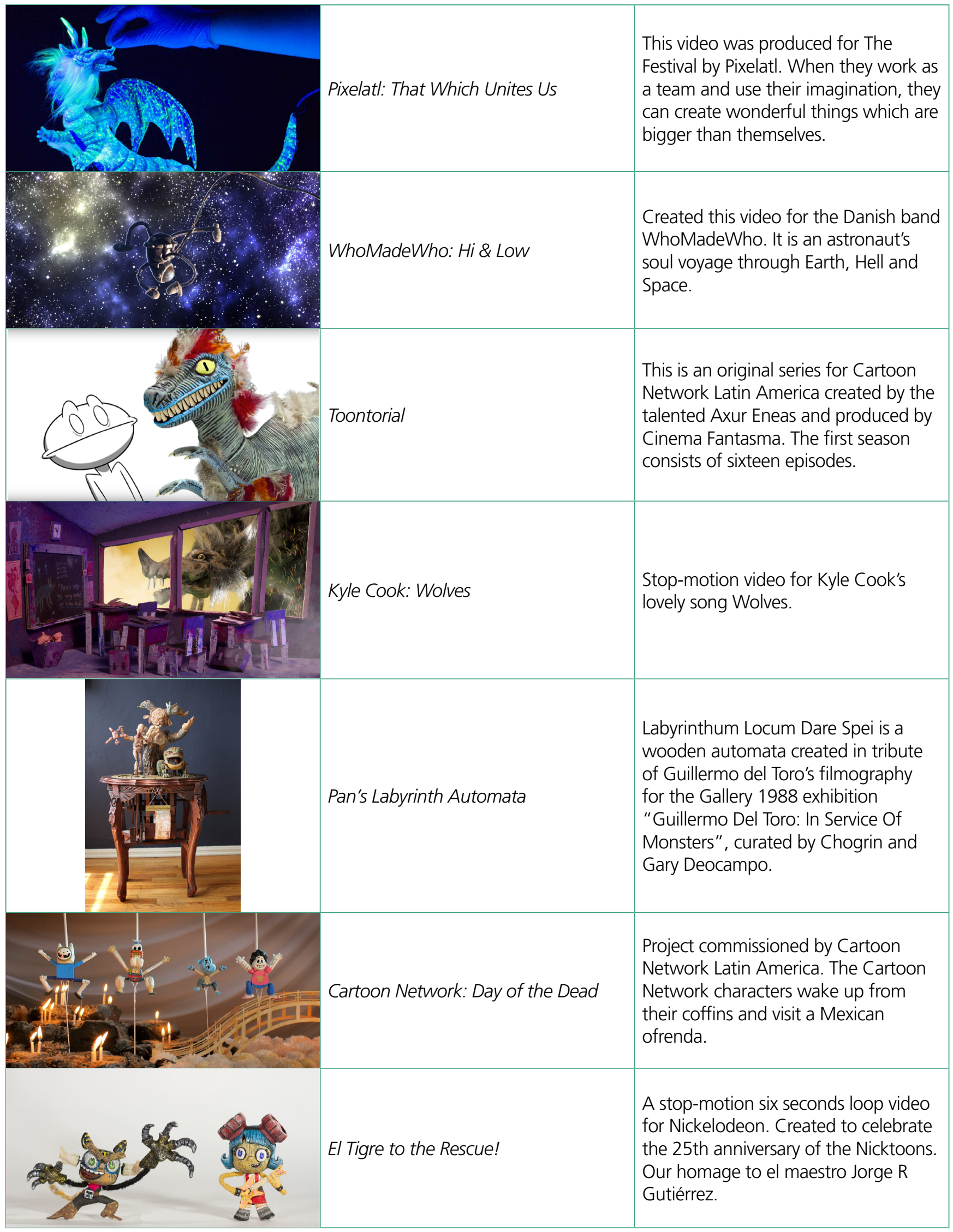




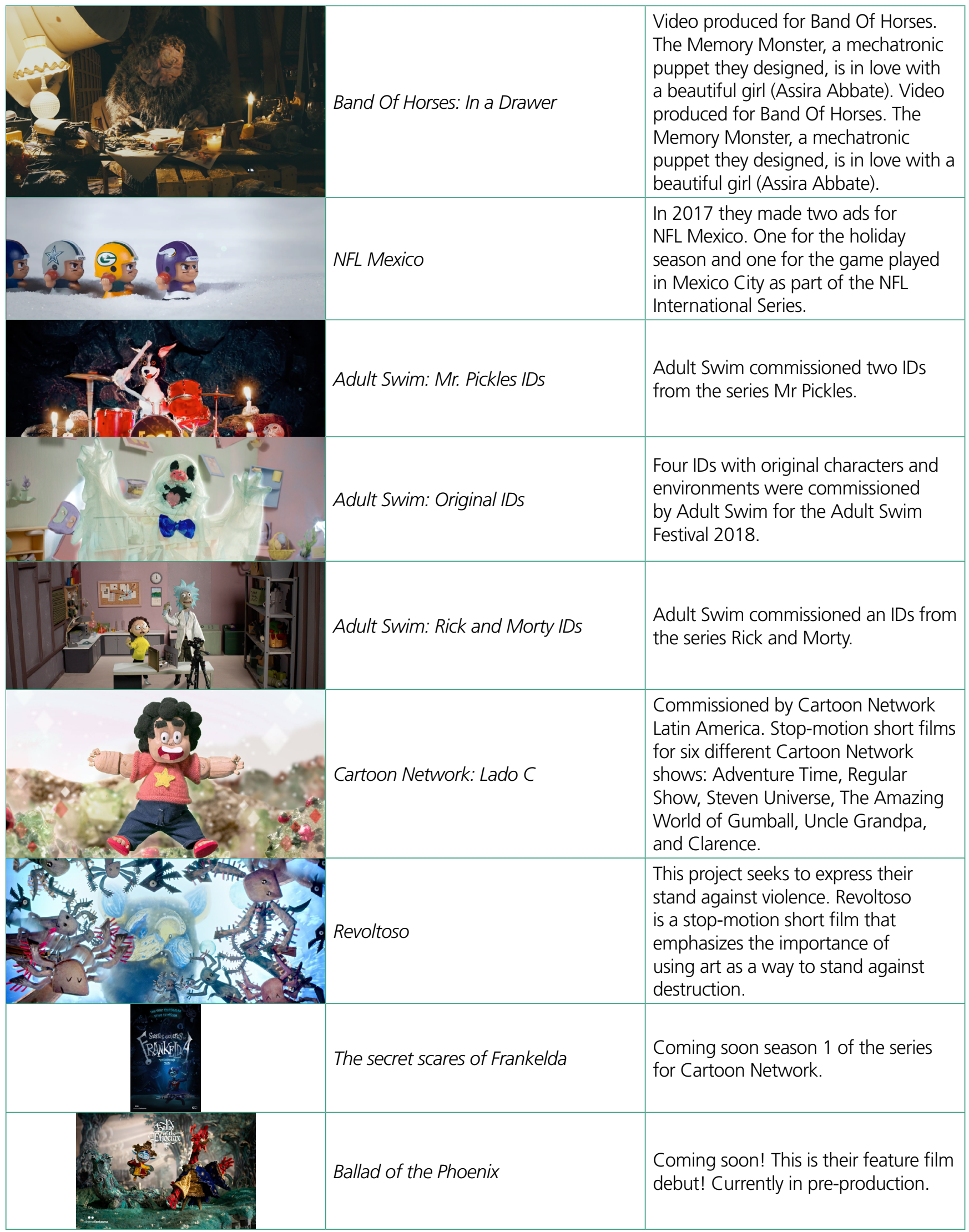




\section{Working as an Organism}

Another key element is that they are a harmonic group that has been growing professionally together. A large part of the team are friends from college with common interests, who continue being friends and have learned to work together (Image 37). Cinema Fantasma does not have a traditional workforce, they have the support of fellow professionals that allows them to have the flexibility to scale the organization according to the project's needs. By doing so, they manage the budget efficiently with no idle costs. In addition, they take advantage of the multiple talents of their staff to achieve the project's completion in a creative and effective way by using their limited resources in a very efficient way.

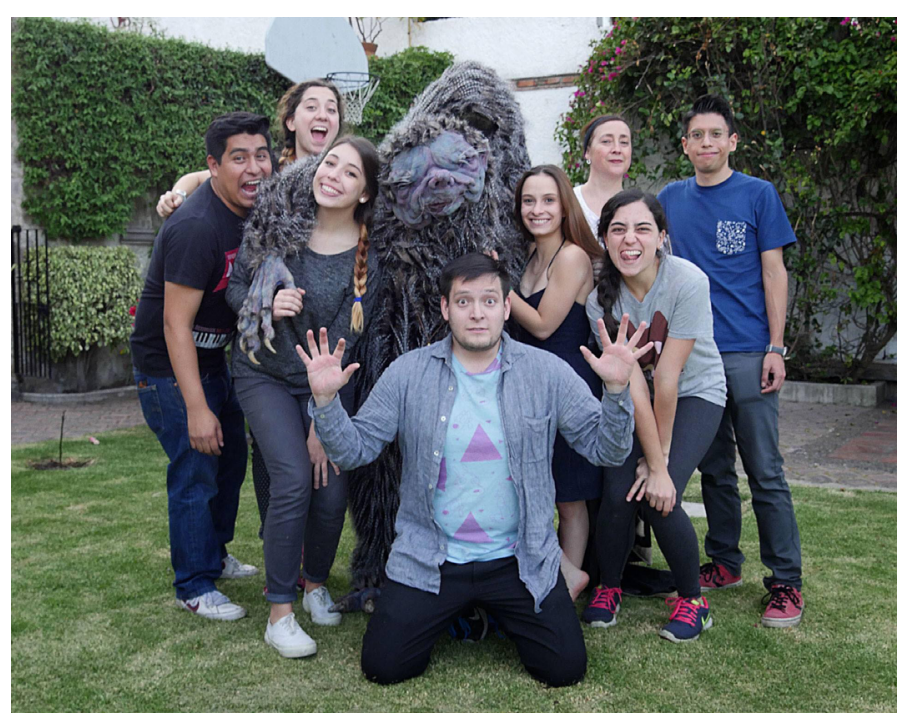

Image 37. The Crew. Source

Retrieved from Cinema Fantasma (2017)

The team has diverse talents from make/up, prosthetics, sculpting and painting artists, graphic designers, film graduates, project managers, to name a few. The profiles needed per project changes according to the script, story and design. This set of abilities makes the team multidisciplinary. Members collaborate in several of the different stages the projects go through. On a day-to-day basis there are people working on the script and the story, while others design and 
sculpt the scenery, props and characters. Most of the time people are rotating from one department to another.

The organization describes a horizontal relationship model (Image 38), except in the case of the Director (Image 39). The Director's job is to ensure that the project is completed with optimum quality, on time and within budget. One of the most important jobs of the direction is to generate new business: this goal requires attending meetings, managing documents and performing public relations activities, among others. The other areas could be considered as stages the projects go through, all under the supervision of direction. There are seven stages: Pre-production, Visual development, Construction, Photography, Animation, Post-production and Sound editing (Image 40). The sound editing usually gets done through outsourcing. Pre-production is an early stage of any film project, including commercials, music videos, short films, and feature films. This crucial step defines how efficient, organized and, ultimately, how successful the production stage will be. It requires knowledge of many facets of production, as well as an ability to prevent potential crises down the line (studiobinder, 2020).

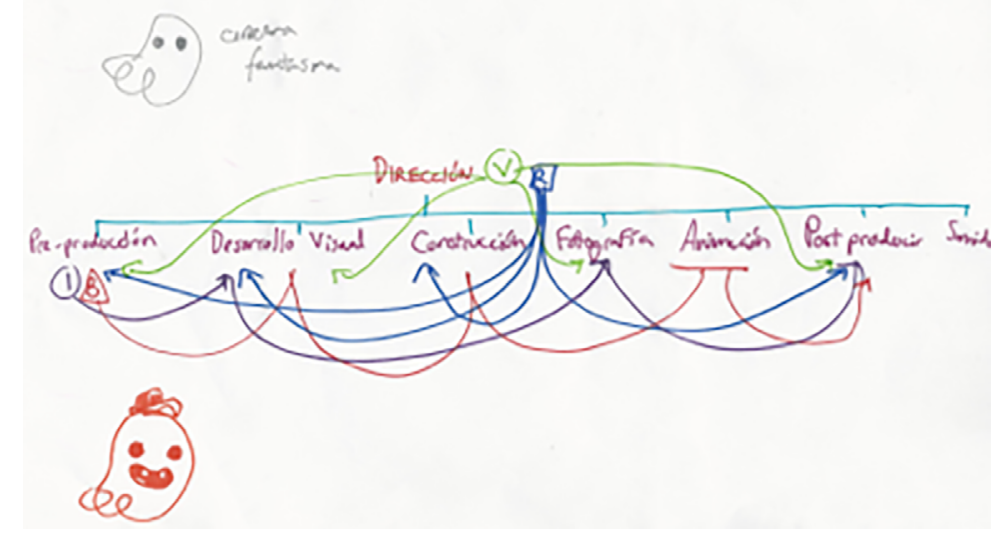

Image 38. Cinema Fantasma organization Source: Retrieved from Cinema Fantasma Personal Archive. 


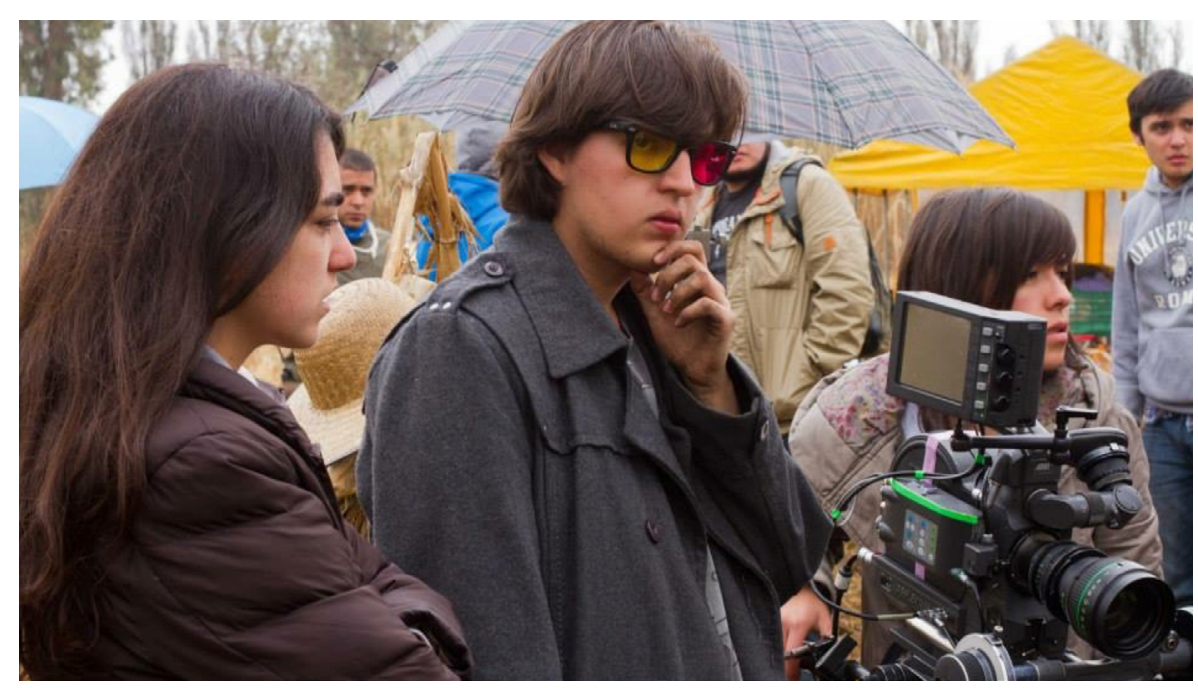

Image 39. Roy while directing his thesis. Source: Retrieved from cinema Fantasma Personal Archive.

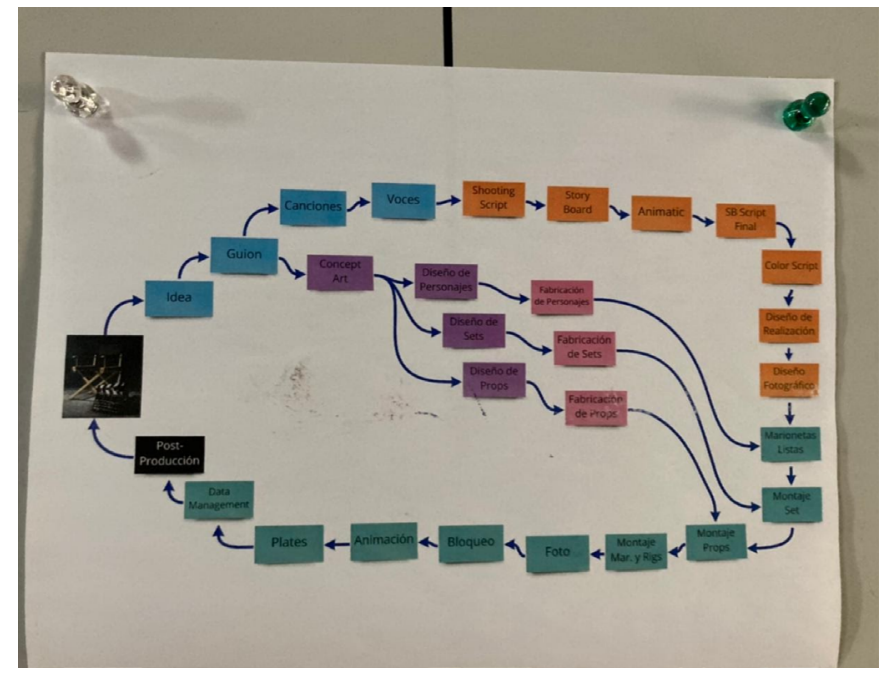

Image 40. Image of the stages the projects could go through. Source: Retrieved from Cinema Fantasma Personal Archive.

Visual development is a building block for any type of visual art, from concept art to graphic design, illustration, animation, and video gaming. The scope gives a level of professional creative control that can be rare. This comes from the versatility of their work being applicable to a wide variety of media formats (Academy of Art University, 2019). Construction phase is where the props and scenery are handmade. In the photography stage they shoot each frame, the puppet is slightly moved and shot again. So when the images are put together to create movement; this is called animating. The interface they use is called DragonFrame, a digital image capture software trusted by major motion picture studios and independent filmmakers alike (DragonFrame, 2020), as seen in 
image 41. Postproduction is the editing of audio and visual materials to create a film. An editor assembles footage shot by shot, adds music (either original or licensed), and incorporates other visual and sound effects. These elements are woven together to create a multi-sensory experience (MasterClass, 2020).

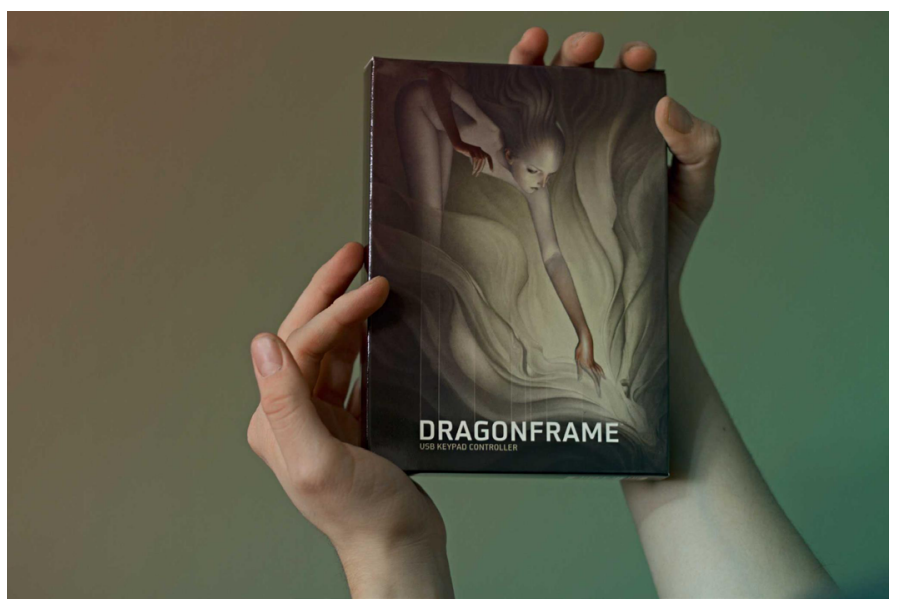

Image 41. Post of the arrival of their interface DragonFrame. Source: Retrieved from Cinema Fantasma (2013b).

Their objective is to deliver turnkey projects, from the script of the original idea to the delivery of the exported video in the format requested to upload on social networks, television or the client's specification according to their needs. The only thing that the client has to worry about, is to tell them what they want and pay them.

\section{SCRUM}

It is a studio with variable needs, in constant change and in need of flexibility; this flexibility has been found through SCRUM. This is one of the agile methodologies designed to guide teams in the iterative and incremental delivery of a product; often referred to as "an agile project management framework," its focus is on the use of an empirical process that allows teams to respond rapidly, efficiently, and effectively to change. SCRUM on the other hand, fixes time and cost in an effort to control requirements. 
The involvement of the business throughout the project is critical as SCRUM relies heavily on the collaboration between the team and the customer by creating the right product in a lean fashion (Sliger, 2011). The tasks are divided week-by-week and day-by-day through a "tracking progress board" where the tasks are separated into four main categories: to do, in process, to verify and done. SCRUM allows the team to have the capacity to organize and plan the different activities with a strict follow up on a day to day basis. The only variable that never moves is the delivery date. SCRUM methodology allows the team to manage projects more effectively by decreasing the amount of overhead dedicated to managing the project (Cervone, 2011). Image 42 shows a diagram of the different elements of the project tool. Cinema Fantasma is used to handcrafted processes and applying SCRUM could not be the exception in the image 43 the board they use with their scheduling, image 44 to 46 are close ups to the board.
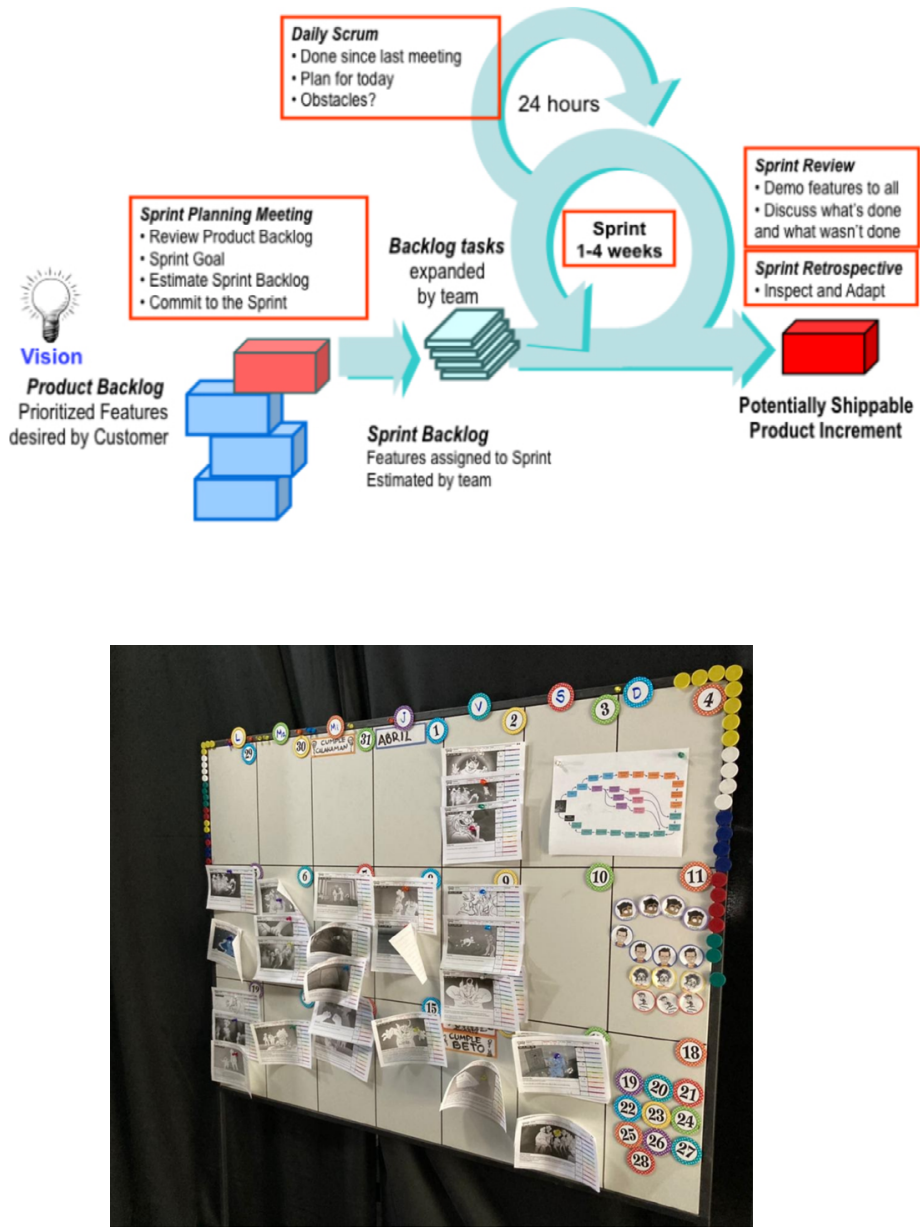

Image 42. SCRUM's diagram. Source: Retrieved from Sliger (2011).
Image 43. Monthly plan with magnets to program easily. Source: Retrieved from Cinema Fantasma Personal Archive. 
Image 44. Close up of the

collaborators to assign jobs. Source:

Retrieved from Cinema Fantasma

Personal Archive.
Image 45 Close up of the board of activities to be assigned. Source: Retrieved from Cinema Fantasma Personal Archive.

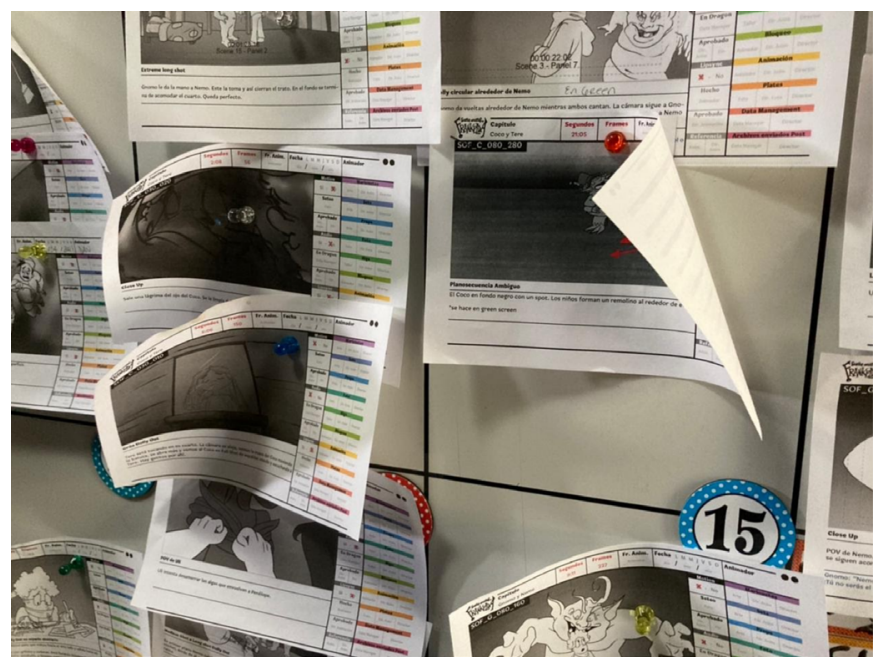

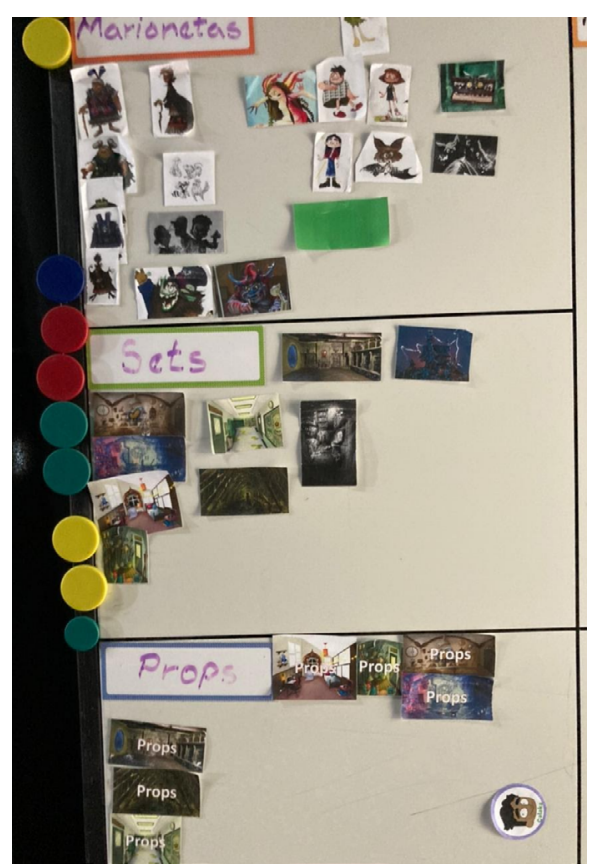

Image 46. Close up to scene design activities and collaborator assigned. Source: Retrieved from Cinema

Fantasma Personal Archive. 


\section{Their work}

Cinema Fantasma has collaborated with successful companies and brands such as NFL Mexico, Adult Swim and Nickelodeon. In 2017 they made two ads for NFL Mexico (Image 47), one for the holiday season and the other for the game played in Mexico City as part of the NFL International Series.

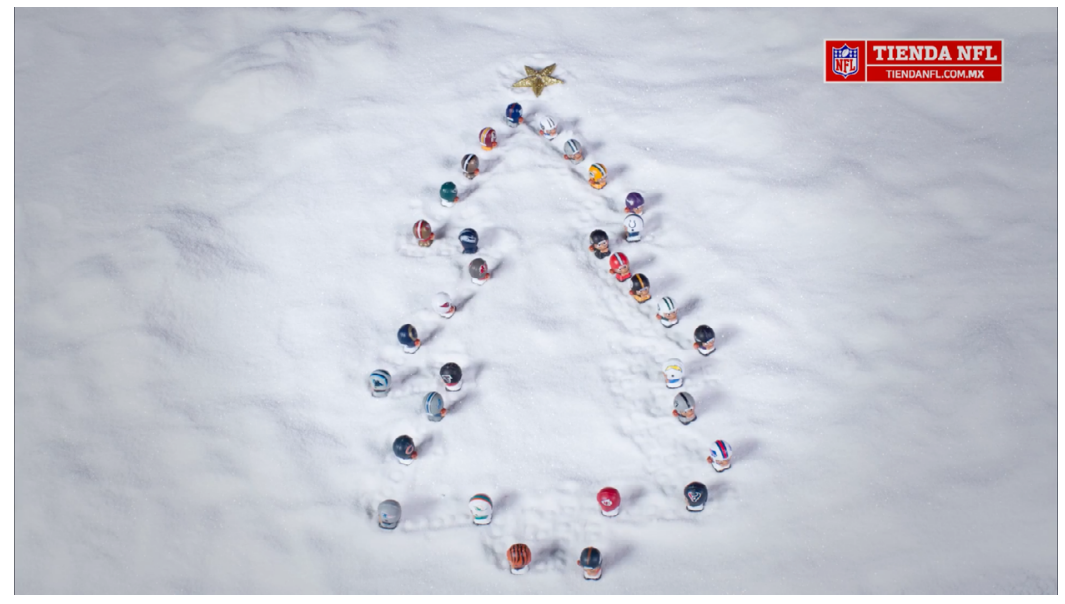

Figure 47. The NFL toys make a Christmas tree in the snow. Source: Retrieved from Cinema Fantasma (2021b).

Four stills with original characters and environments were commissioned by Adult Swim for the Adult Swim Festival 2018. Werewolf focuses on character comedy, Blue God in Space focuses on an overall mystic mood, Tiger Knight v. Rhino Knight focuses on treating a usual setting as if it were normal, and Dancing Ghost focuses on animating each item of an entire room. A stop-motion of six seconds loop video was made for Nickelodeon, created to celebrate the 25th anniversary of the Nicktoons with an homage to Emmy winner Jorge R. Gutiérrez 6 (Image 48). 


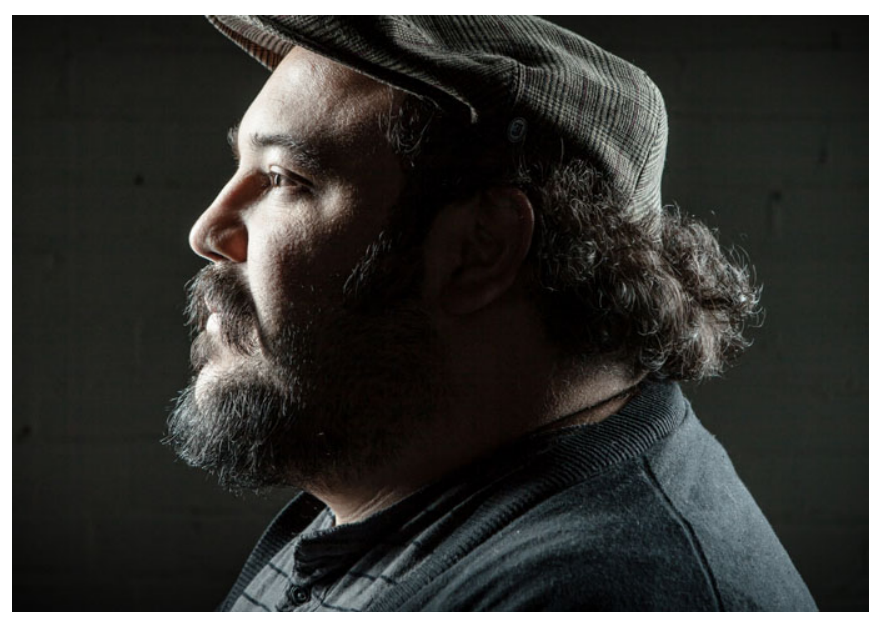

Image 48. Jorge R. Gutierrez.

Source: Retrieved from

Equihua (2018).

\section{Turning points}

Cinema Fantasma has showcased at international festivals even winning several awards for their work and have developed many projects. However, there have been three key milestones for the studio.

The first one was when, after a Kickstarter campaign for their project Revoltoso ${ }^{7}$ (Figure 49), Guillermo del Toro heard about them and became their mentor and friend. His support made a dramatic change from one day to the other; helped them grow and attracted clients.

Cinema Fantasma is an exemplary group. Their absolute passion for animated films leads them to invent new forms of production and financing. Definitely a group to take into account: creative, free and full of vitality - Guillermo del Toro (Cinema Fantasma, 2021a). 


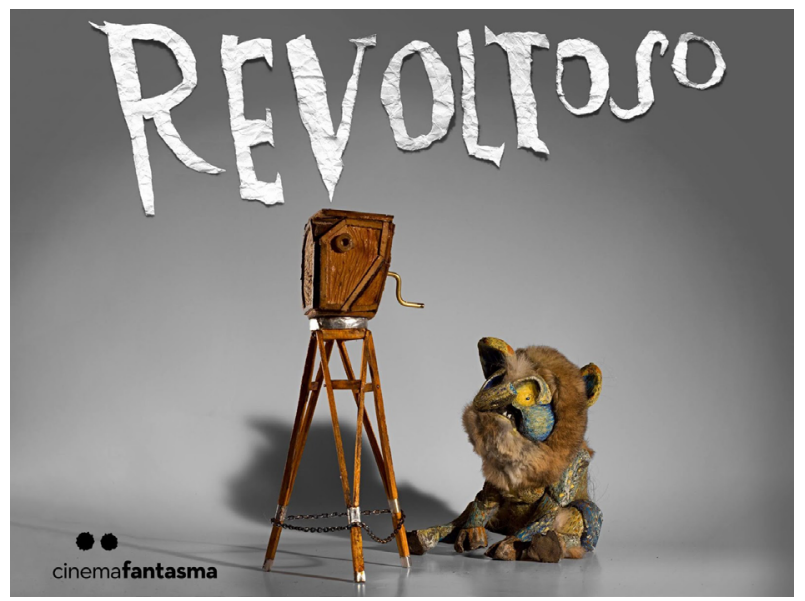

Image 49. Revoltoso. Source: Retrieved from Cinema Fantasma (2014b).

The second one is when Cartoon Network entrusted them with the making of a series of seven short films, which gave them exposure around the world. In an interview Irene Melis talks about this moment mentioning the following:

\section{After Revoltoso, Cartoon Network was our first professional project and happened because we went to several festivals, specially Pixelatl ${ }^{8}$ [...] After knocking on several doors we decided to make a mini short film with two puppets of the Regular Show and we sent it, they liked the idea so they gave the six chapters of the Lado $C$ series (Rios, 2020).}

The series name comes from the idea of the B side of a tape but with the $C$ for Cartoon Network: Adventure Time ${ }^{9}$, Regular Show ${ }^{10}$, Steven Universe ${ }^{11}$, The Amazing World of Gumball12, Uncle Grandpa ${ }^{13}$, and Clarence ${ }^{14}$ (Rios, 2020). In 2020, because of the success of the pilot of The secret scares of Frankelda in Cartoon Network It was presented in Pixelatl the animation festival and it was

\footnotetext{
9 Watch the full video in: https://vimeo.com/145461623

10 Watch the full video in: https://vimeo.com/14546162

11 Watch the full video in: https://vimeo.com/145460204

12 Watch the full video in: https://vimeo.com/145460131

13 Watch the full video in: https://vimeo.com/145461621

14 Watch the full video in: https://vimeo.com/145460130
}

8 Pixelatl is a Mexican Association dedicated in promoting the creation and dissemination of graphic and audiovisual content and narratives, to expand the national offer and extend its audiences within and outside the country. Seeking to develop the Mexican Multimedia Industry so that it is relevant among the Industry, and becomes a lever for development, dignity and reconciliation for the Country (Staff Pixelatl, 2012). 
announced that HBO Max ${ }^{15}$ commissioned a special broadcast of twenty two minutes, the second longest stop animation project in Mexico after Revoltoso. Frankelda's Book of Spooks is just one of more than 100 projects HBO Max plans to develop in Latin America in the next two years, and will tell a different creepy tale in each episode; five 7-minute episodes have been commissioned (Dudok, 2021).

\section{Challenges}

The first challenge the studio faced was finding funding for their first official project. In the case of Revoltoso, the project took five years to complete. First of all, they started with friends and family funding either in money, in-kind or professional services. Secondly, they applied to funding through platforms like Fondeadora (Non existent anymore, since it transformed into another project and fusioned with Kickstarter $\left.{ }^{16}\right)$ and Kickstarter. Lastly, they looked for alliances with associate producers, associate coproducers and executive producers. For example, a Mexican producer invested one million pesos on the project and a producer from New York City provided one hundred thousand dollars.

During their first meeting in New York, the investor asked them who else could be interested in the project. They said the MoMA -The Museum of Modern Art-- and Cartoon Network on the top of their mind. The producer asked them to obtain the contact information of someone that could be interested in the project. It became like a treasure hunt adventure, finding the locations where they could go and running through NYC to knock on doors. They managed to meet the film curator at MoMA and Directors at Cartoon Network, which began a professional relationship that has lasted until today. Any entrepreneur, content creator and artist struggles to achieve their first milestone but every pebble is a

15 Cartoon Network, HBO Max, and its late-night brand Adult Swim is owned by Warnermedia.

16 A crowdfunding platform that became the largest in Latin America. Now, those same young people will seek to challenge the financial system and turn their project into a digital bank, offering free debit cards and accounts (Sánchez, 2018). 
stepping stone even when nothing comes from it besides building confidence. There are two ideas that they have to keep in mind each step of the way "fake it, till you make it" by believing in the team and the product, idea or service and "you already have a no, so you have nothing to lose". Hard work and these principles are important to get encouraged and remembering that there is more gain in trying and failing than not trying at all. But most importantly believing in the product or service.

Cinema Fantasma has also learned that when hired, they must stay true to their principles and clarify that the project will be with the look and feel of the studio, assuring the client that the delivery will be with exceptional quality and transparency in the process with weekly reports and accessibility to review the schedule. This strategy has worked with most of their clients. In their own words:

We try to do things the way we think they are right. We are against making movies based on market research or what people are supposed to want. We rather ask ourselves, What do we mean? What do we need to say? And then we think of a story and create characters (Ambriz, personal communication, 2021a).

For example, with Santillana ${ }^{17}$, the initial request was six shorts for elementary school. The client provided the team with the character design and storyline. However, it gave them creative freedom (Ambriz, personal communication, 2021a).

The quality of the first delivered shortly was so outstanding that the contract immediately got duplicated, giving them the production of twelve additional shorts for elementary school and would also give them the production for the preschool or high school shorts afterward, going from medium to an extensive project (Ambriz, personal communication, 2020a).

17 An International Editorial Company that works for education in a large number of countries offering materials for each educational level (Santillana, 2021). 
Unfortunately, when the client has tried to control the project, it becomes complicated, and often it does not get completed. For example, in the case of a project for a worldwide renowned soda brand. They could not make any decisions on the process, so the creativity did not flow; also, the project was checked every step of the way. Every decision, detail, and shot had to be approved. The team got so frustrated they wanted to finish the relationship on the spot; after negotiating and a settlement that worked for both sides, they could quit the project (Ambriz, personal communication, 2020a).

Cinema Fantasma is the option for brands that want to show something new, different. Their clients are looking for shocking, trendy videos to generate interactions on social media, for example.

\section{The Studio Nowadays}

Currently, the studio is working on a feature film that is at the final script review, after fifteen treatments, and about to have the voices recorded; the project was awarded with a contribution of almost six millions Mexican pesos from FIDECINE$\mathrm{IMCINE}^{18}$ for the production, post-production, distribution, and exhibition of feature films (75 minutes or more) of fiction and/or animation through the investment of venture capital and/or the provision of credits (Table 2). The guidelines of this funding involve the co-participation of the filmmakers and other investors, so at present time Vonno and Roy are raising capital to carry out their film.

\footnotetext{
18The escrow of the Instituto Mexicano de Cinematografía (IMCINE) for the Production, post-production, distribution and exhibition of feature films (75 minutes or more) of fiction and / or animation through the investment of venture capital and / or the provision of credits. FIDECINE seeks to provide this system of financial and investment support for producers, distributors, marketers and exhibitors of national films; as an industry fund, the aim to stimulate the participation of the public, social and private sectors, through the comprehensive reactivation of the national film industry (FIDECINE, 2019).
} 
Table 2. Results of the second call for FIDECINE 2019 in Production and Postproduction support.

\begin{tabular}{|c|c|c|c|c|}
\hline $\begin{array}{c}\text { Accepted Project } \\
\text { Number }\end{array}$ & Project Number & Title & Applicant & ${ }^{\mathrm{a} A m o u n t}$ Approved \\
\hline 1 & 93 & Heróico & $\begin{array}{c}\text { New Fiction Films S. } \\
\text { de R.L. de C.V. }\end{array}$ & $\$ 5,000,000.00$ \\
\hline 2 & 52 & $\begin{array}{c}\text { El día que todo } \\
\text { cambió }\end{array}$ & $\begin{array}{c}\text { Los Güeros Films S.A. } \\
\text { de C.V. }\end{array}$ & $\$ 6,000,000.00$ \\
\hline 3 & 107 & La manzana de Adán & $\begin{array}{c}\text { Cinestereo S.A. de } \\
\text { C.V. }\end{array}$ & $\$ 6,000,000.00$ \\
\hline 4 & 97 & El ojo de los días & $\begin{array}{c}\text { Protopictures S.A. de } \\
\text { C.V }\end{array}$ & $\$ 6,000,000.00$ \\
\hline 5 & 159 & $\begin{array}{l}\text { Los demonios del } \\
\text { amanecer }\end{array}$ & $\begin{array}{c}\text { Julián Hernández } \\
\text { Pérez }\end{array}$ & $\$ 6,000,000.00$ \\
\hline 6 & 162 & El tajo & $\begin{array}{c}\text { Dana Annie Rotberg } \\
\text { Goldsmit }\end{array}$ & $\$ 6,000,000.00$ \\
\hline 7 & 46 & $\begin{array}{c}\text { Estos tiempos, estos } \\
\text { días }\end{array}$ & $\begin{array}{c}\text { Iliana Verónica Reyes } \\
\text { Chávez }\end{array}$ & $\$ 6,000,000.00$ \\
\hline 8 & 84 & Guerrero & $\begin{array}{l}\text { Sumo Cinema Digital } \\
\text { Color S.A. de C.V. }\end{array}$ & $\$ 6,000,000.00$ \\
\hline 9 & 127 & La balada del Fénix & $\begin{array}{c}\text { Espacio Creativo } \\
\text { Fantasma S.A. de C.V. }\end{array}$ & $\$ 5,999,097.00$ \\
\hline 10 & 90 & El camión & $\begin{array}{c}\text { Pocket Pictures S.A. } \\
\text { de C.V. }\end{array}$ & $\$ 6,000,000.00$ \\
\hline \multicolumn{4}{|c|}{ Total } & $\$ 58,999,097.00$ \\
\hline
\end{tabular}


The film has already won two festivals: one in Mexico and the other in Buenos Aires, and in June 2019, they attended a festival in France. Film Festivals are a means to exposure; they are not always easy to get into and can elevate a film's perception because they are juried (Gasek, 2012; Lyons, 2012). There are four key reasons to exhibit films at festivals. First, the film is screened in front of acquisition executives, who may discover the film and might make an offer on the spot. Second, the prestige the award brings to the filmmakers. The third reason is to sit on a panel and/or take part in questions and answers sessions. Last but not least, attending festivals gets the film reviewed (Grove, 2018; Kredell et al., 2016). The table 3 enlists the festivals their short film Revoltoso was at and which awards were given (Image 50). Image 51 is a post Cinema Fantasma made for their trip to Japan to screen Revoltoso.

\section{Table 3. Festivals where Revoltoso participated.}

\begin{tabular}{c|c|c} 
Festival & Year & Award \\
\hline Animasivo & 2016 & \\
\hline $\begin{array}{c}\text { Boston Latino International Film } \\
\text { Festival }\end{array}$ & 2016 & \\
\hline $\begin{array}{c}\text { Downtown Film Festival LA } \\
\text { Festival Latinoamericano de Cine } \\
\text { Independiente Bahía Blanca }\end{array}$ & 2016 & \\
\hline Long Beach Indie International Film & 2016 & \\
\hline Pixelatl El Festival & 2016 & \\
\hline Portsmouth International Film Festival & 2016 & \\
\hline Shorts México & 2016 & \\
\hline Festival de Cine de Bogotá & 2016 & \\
\hline "MIRA" Festival de Cine & 2016 & \\
\hline Latinoamericano Independiente & 2016 & \\
\hline Festival de Cine y Artes Visuales \\
Bugarte & 2016 & \\
\hline Festival Internacional de Cine de & Mejor Animación \\
\hline Morelia & 2016 & \\
\hline Oaxaca Film Festival & 2016 & \\
\hline Sitges Film Festival & & \\
\hline Stoptrik FF & & \\
\hline
\end{tabular}




\begin{tabular}{|c|c|c|}
\hline Cut Out & 2016 & \\
\hline St. Louis International Film Festival & 2016 & \\
\hline River Film Festival & 2016 & \\
\hline Animation Attack & 2016 & \\
\hline Carmarthen Bay Film Festival & 2016 & \\
\hline Philadelphia Independent Film Festival & 2016 & \\
\hline Promofest, Short of the Week & 2016 & Special Jury Mention \\
\hline $\begin{array}{l}\text { El Ventilador, Festival de Cine de } \\
\text { Animación }\end{array}$ & 2016 & \\
\hline Canada International Film Festival & 2016 & Excellence Award \\
\hline Cinequest & 2016 & \\
\hline Manchester Film Festival & 2016 & \\
\hline Open World Animation Festival & 2016 & \\
\hline Brooklyn Film Festival & 2016 & Best Original Score \\
\hline Ferrara Film Festival & 2016 & \\
\hline $\begin{array}{l}\text { Festival Internacional de Cine de } \\
\text { Huesca }\end{array}$ & 2016 & \\
\hline Santa Cruz Film Festival & 2016 & \\
\hline Fantasia International Film Festival & 2016 & \\
\hline Guanajuato International Film Festival & 2016 & \\
\hline $\begin{array}{l}\text { Festival Internacional de Cine de } \\
\text { Hermosillo }\end{array}$ & 2016 & \\
\hline Ariano International Film Festival & 2016 & \\
\hline $\begin{array}{c}\text { Belo Horizonte International Short Film } \\
\text { Festival }\end{array}$ & 2016 & \\
\hline $\begin{array}{c}\text { Festival Internacional de Cine de } \\
\text { Monterrey }\end{array}$ & 2016 & \\
\hline $\begin{array}{l}\text { Ramunas Atelier International } \\
\text { Independent Film Festival }\end{array}$ & 2016 & \\
\hline Arizona International Film Festival & 2016 & $\begin{array}{l}\text { Special Jury Award for innovative } \\
\text { animation }\end{array}$ \\
\hline Athens Animfest & 2016 & Special Mention \\
\hline Humboldt International Film Festival & 2016 & $\begin{array}{l}\text { Honorable Mention Honorable } \\
\text { Mention }\end{array}$ \\
\hline Louisiana International Film Festival & 2016 & \\
\hline $\begin{array}{l}\text { Athens International Short Film Festival } \\
\text { "Psarokokalo" }\end{array}$ & 2016 & \\
\hline Campeche Film Festival & 2016 & \\
\hline $\begin{array}{l}\text { MUMIA - Mostra Udigrudi Mundial de } \\
\text { Animação }\end{array}$ & 2016 & \\
\hline Sydney Independent Film Festival & 2016 & Best Animation \\
\hline Lublin Film Festival & 2017 & \\
\hline ArteCareyes & 2017 & \\
\hline $\begin{array}{c}\text { Festival Internacional de Cine Álamos } \\
\text { Mágico }\end{array}$ & 2017 & \\
\hline
\end{tabular}




\begin{tabular}{c|c|c}
\hline Japan Media Arts Festival & 2017 & New Face Award \\
\hline $\begin{array}{c}\text { Brasil Stop Motion International Film } \\
\text { Festival }\end{array}$ & 2017 & Callejón Sur \\
\hline Callejón Sur & 2017 & \\
\hline Tlanchana Fest & 2017 & \\
\hline Ann Arbor Film Festival & 2017 &
\end{tabular}
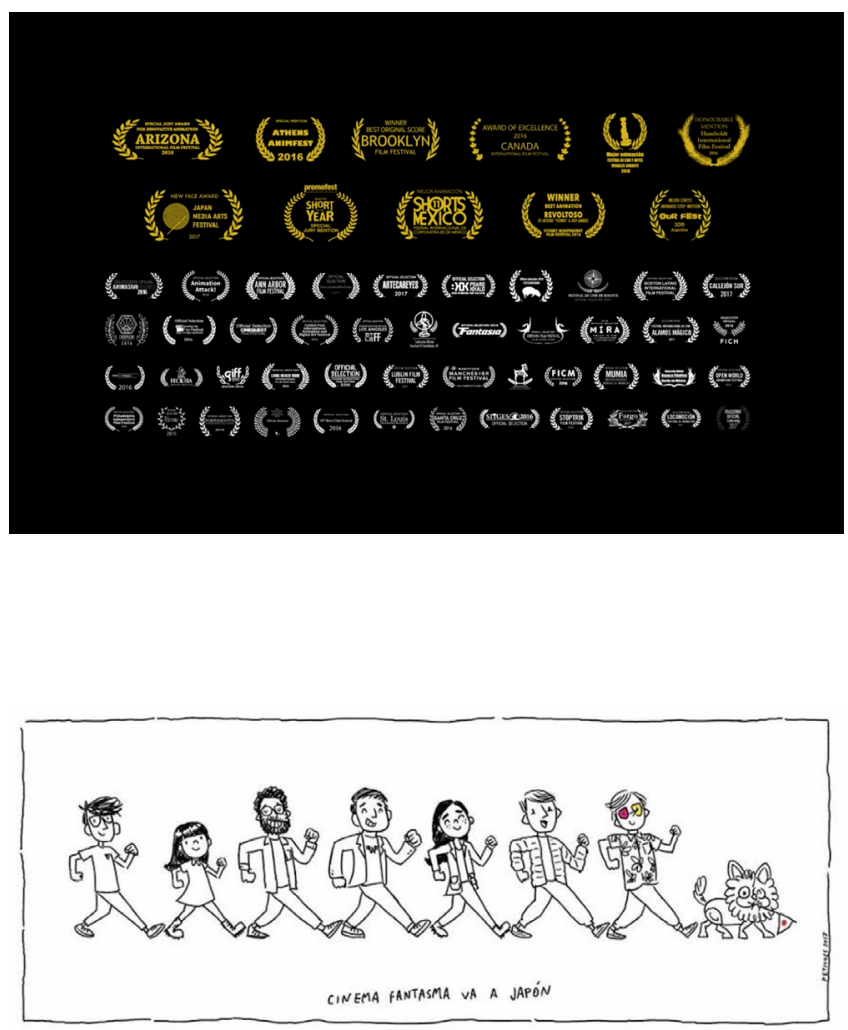

Image 50. Festivals where Revoltoso

has participated. Source: Retrieved

from Cinema Fantasma Personal

Archive.

The series created, written, designed and made $100 \%$ by them for Cartoon Network that consisted of ten episodes called The secret scares of Frankelda (Image 52) had a tremendous success that they are working with a more ambitious project with Cartoon Network who decided to convert into a series of five chapters with an approximate time of twenty minutes each. 


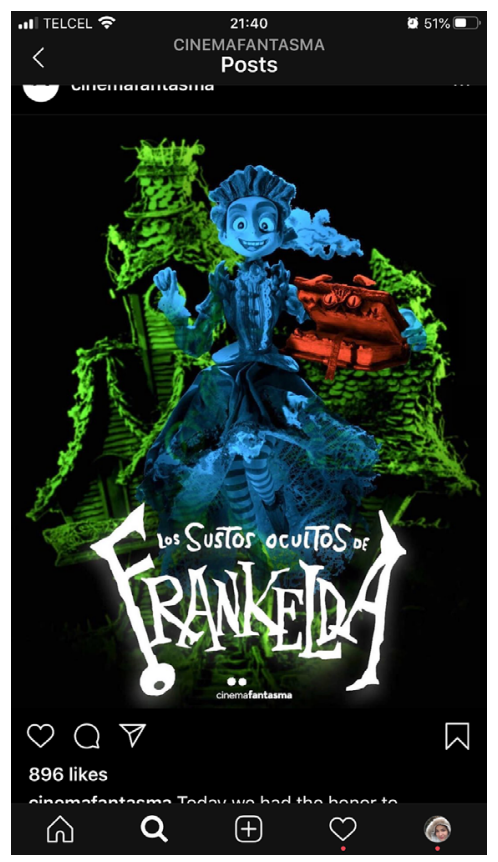

Image 52. Instagram post announcing The secret scares of Frankelda. Source: Retrieved from Cinema Fantasma (2019).

Some of the reasons why The secret scares of Frankelda pilot is considered a success is: that even though the show did not have an advertisement campaign it had a lot of views; the great difference ratio between the likes $(25,171)$ and dislikes (343) ratio ${ }^{19}$ (Image 53); the studio also received lots of fanart (drawings done by the fans); and most interesting is that the most common search is Frankelda episode two (Image 54), which meant that people were hooked and wanted to see more.

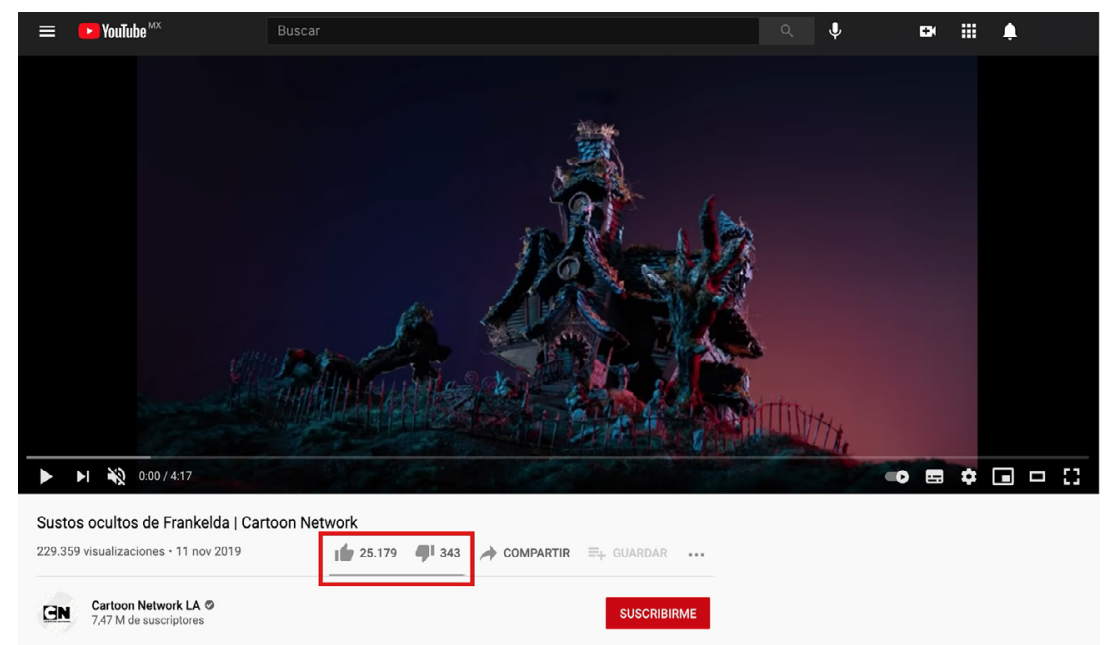

Image 53. Screenshot of The secret scares of Frankelda on Youtube. Source: Retrieved from Cartoon Network LA (2019). 
In summary, for the 2020 they will continue working on their feature film The Ballad of the Phoenix and their series and short film of The secret scares of Frankelda and their project with Santillana has continued growing. The team looks forward to retiring from small commercial projects.

The Ambriz brothers have demonstrated their tenacity, talent and ability to create stop motion animation projects of the highest quality. I believe in their ability to make this feature film The Ballad of the Phoenix; a new jewel of Mexican Cinema. - Jorge R. Gutierrez (Cinema Fantasma, 2021a).

\section{Side Project: Cinema Edu}

\section{Alberto "Chino" Rodriguez ${ }^{20}$ (Image 55) mentioned in an interview for Rolling Stones that:}

It is very difficult [making animation in Mexico], the good animators in the world are very few and if you add the lack of specialized schools and the fact that the work area is not as abundant as we would like, it is difficult. However, it should be noted that it is extremely enriching that animators are generally young people with a great desire to learn and who put their soul into this profession, that by the age of forty they are already masters in animation and that is when they begin teaching others (Staff Rolling Stone Mexico, 2020).

20 Alberto "Chino" Rodríguez is an example of tenacity and talent. His passion for animation led him to start his professional career in different production houses, doing commercials and independent audiovisual projects. In 2004 he was part of Ánima Estudios as editor, in 2006 he produced and directed the first two seasons of the successful animated series El Chavo animated and in 2010 he directed his first animated feature entitled AAA without limit in time. He has made four films in the saga of Las leyendas: The Legend of La Llorona (2011), The Legend of the Mummies of Guanajuato (2015) -nominated for the Platinum Awards in the category of Best Ibero-American Animated Film-, The Legend of Chupacabras (2016) -winner of the Best Animated Film at the 2017 Luminus Awards- and The Legend of Charro Negro which was released in 2018. 


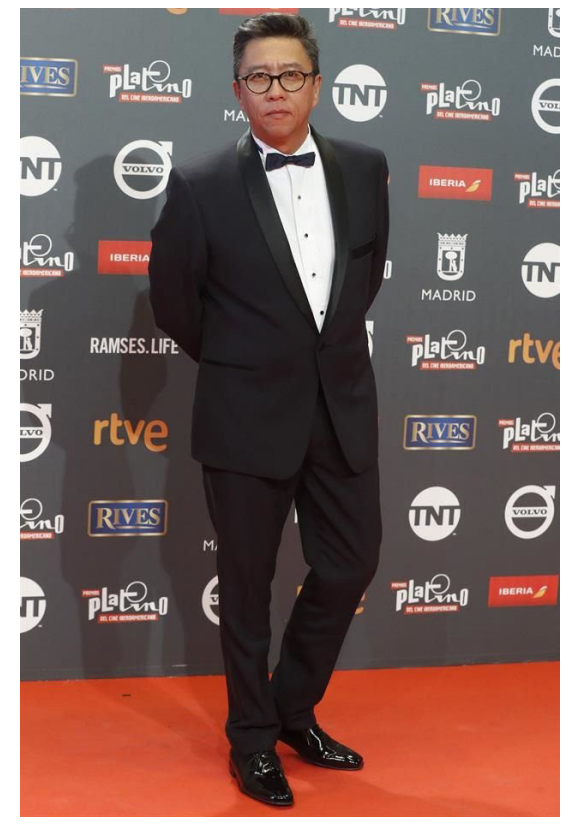

mage 55. Alberto "Chino"

Rodriguez. Source: Retrieved from Santiago (2017).

Cinema Fantasma realized that there was a need in the market to learn about animation processes and methods. In addition, following the teachings of del Toro to aid other filmmakers and share the knowledge (Staff Rolling Stone Mexico, 2020). Therefore they created Cinema Fantasma Edu (Image 56), where they offer courses, workshops and certificates where students learn hands-on from their studio and workshop. The program had enrolled generations of forty students each two years in a row (Image 57). They believe in sharing their knowledge to strengthen the community, in this case the animation community. The program was hands-on and the exercises delivered by their students were good quality. The students came out happy with their experience according to the feedback given. Most important, this project allows them to find future collaborators for the studio. Unfortunately, the program had a setback with the Covid-19 restrictions, no visitors are allowed in the premises. However, they are hoping to launch a virtual course once they have some time to plan because for now their team is focused on delivering their projects. 


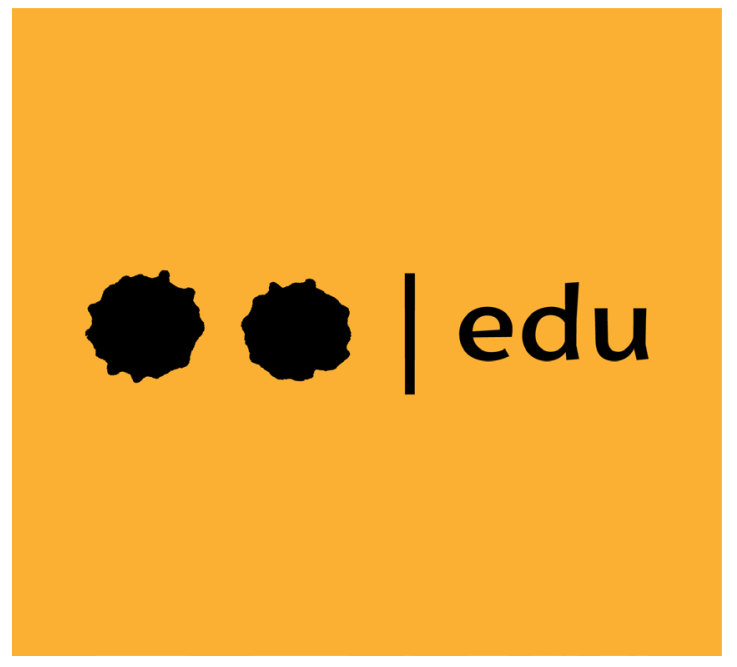

Image 56. Cinema Fantasma

Edu. Source: Retrieved from

Cinema Fantasma (2021c).

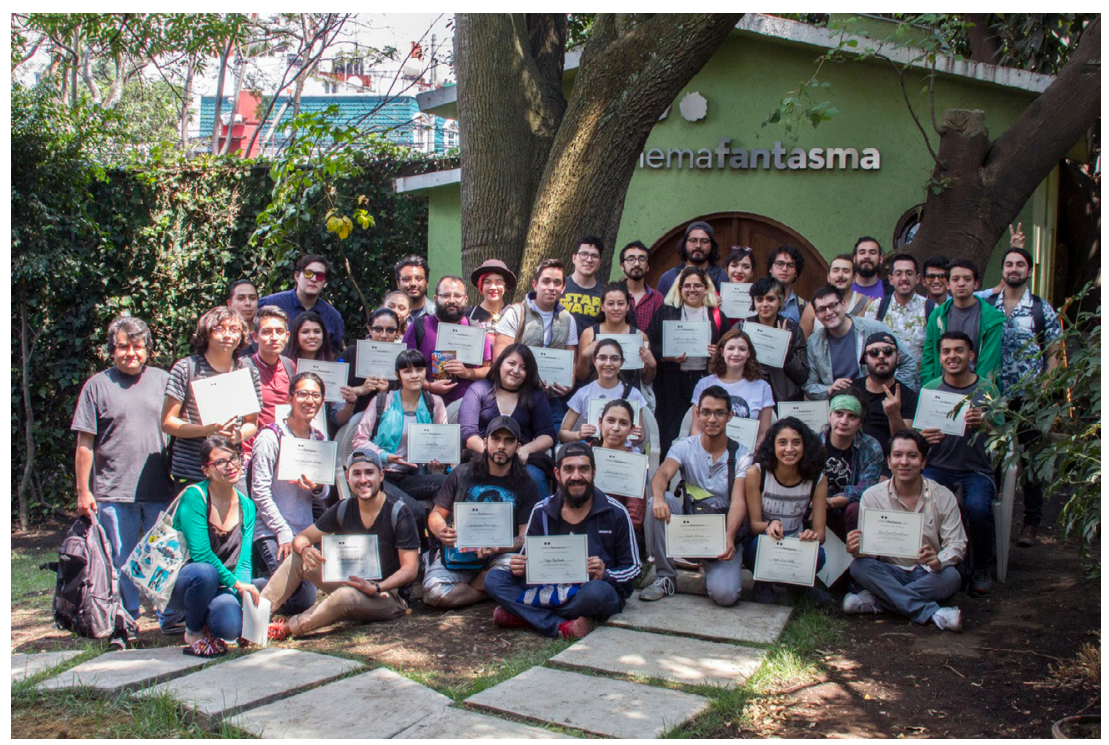

Image 57. Graduation phote

of their certification. Source

Retrieved from Cinema

Fantasma (2021c)

\section{Conclusion}

Success could be measured by different factors. Currently money factors are the top of mind: return of investment, economic growth, revenue, among others. However, there should be other factors considered for measuring success. In the case of Cinema Fantasma even when the studio is considered to be successful because of the recognition they are getting; the efficacy and efficiency in their process (for example the reduction in their shooting times); and the collaborations they have with renowned brands. The situation that persistently challenges the studio is obtaining a consistent income. They consider it convenient to keep the studio open between projects and investing their profits in their original 
projects. Their purpose is to dissolve the commercial area and make a living out of their own original films and series.

As discussed previously Animation is not a new genre, yet it is the one of the least explored in Mexico. In spite of that, Cinema Fantasma found in it a way to express their vision and values to tell their stories. They have found a way to generate income for their families, friends and collaborators. These days it is important to create a source of income especially in the creative areas. Usually artisans, painters, sculptures, etc. are usually striving to survive and have to find other activities to pay for their expenses and their art. Cinema Fantasma is an example that hard work can create an opportunity for this trade.

One of the most important lessons to be learned from this case is to be true to the vision and values. To not compromise them in order to get a job, the teaching of "the client is always right" should transform and evolve. As seen in this case study when the studio settled their projects to only the clients wants and visions the projects could not even be completed. It is fundamental to learn from them and start staying true to the company's path. When creating a new project, company, or startup the focus should be on a problem and finding a solution that does not go against the personal values of the founders and team. In addition to focusing on creating a product or service new business should focus on creating value not only for the client or consumers but also for the employees, collaborators, suppliers and everyone involved. As Vonno mentioned it is important to deliver on time with quality but without affecting the quality of life of our collaborators. (Ambriz, personal communication, 2021b) Innovation should be found not only in the finished product or service but in the process; the reduction in resources and time; to mention some without ever conceding in quality and end products.

In Mexico, $83 \%$ of the companies are family-owned, and most of them are small and medium-sized, which generate $67 \%$ of employment in the country, which 
is why they represent an important part of the economy. However, there are no studies on the difficulties they face, their administrative and government makeup (Rodriguez, 2017). Cinema Fantasma was explored for this case study because this type of business models are in the least explored. Finding small successful studio cases are scarce. Even though small family owned businesses are fundamental in Mexico's economy. The idea behind this case study is to empower students and anyone interested in exploring the film industry, specially, in creating and finding their own opportunities. To not settle working for others that in the end will see them as a number or a means to their own ends. On a personal level, personal success is taught to be measured by salary and professional status. Nonetheless, they should not be the only ones to consider such as mental and physical health, spare and leisure time (Image 58).

There is no single way to measure success, there are many factors that accompany it and that are part of your professional and personal life (@UniAsturias, 2021).

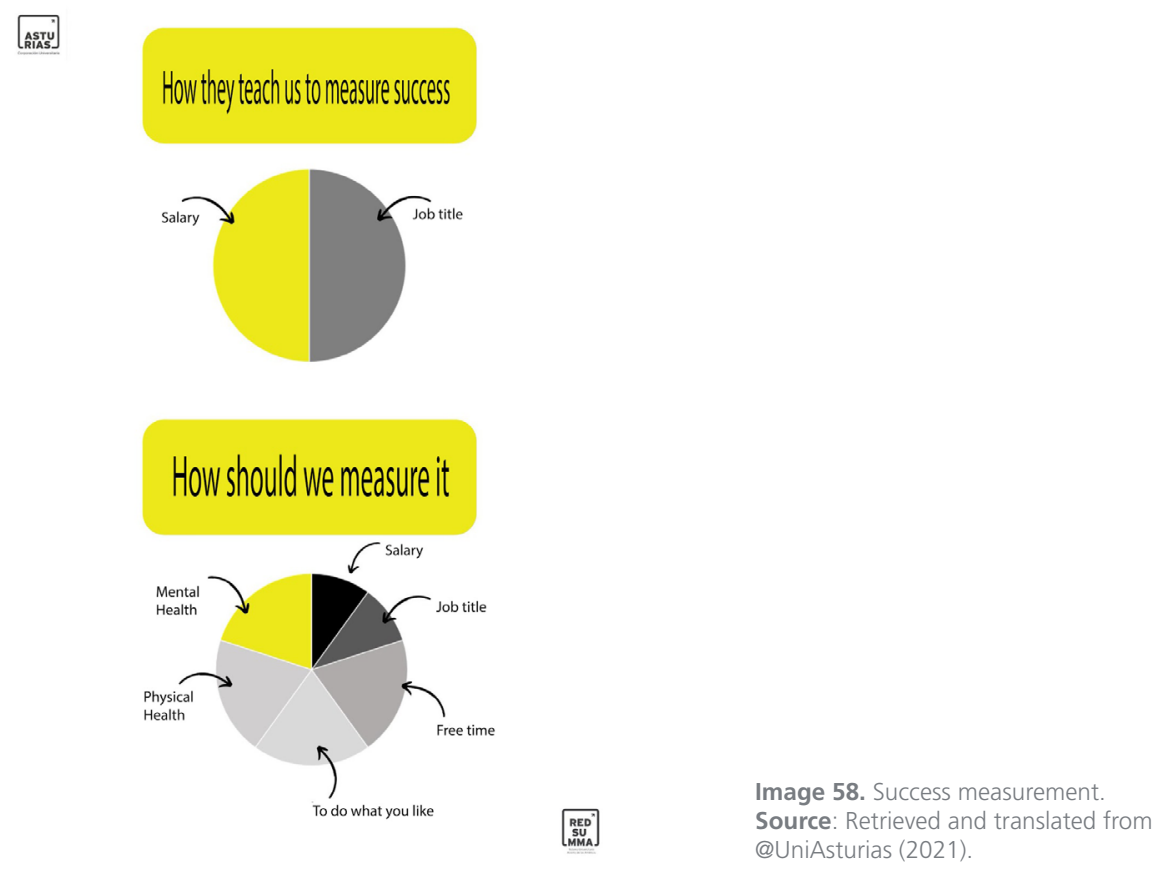


On the other hand, having an animation, art, and film studio is a challenge. To dedicate to making film and animation, there must be passion in doing it. In the words of Vonno:

Cinema is very difficult, no one tells you that there is almost no money. So, if they love it, they should do it, and if they have doubts, then maybe it is not their thing. Because this profession involves a lot of sacrifice. It's like Game of Thrones' ${ }^{1}$. They say that the principal point of Game of Thrones is that you either win or die. It is a huge bet; it is risking the family patrimony; risking your health; your mental integrity; and if cinema is what you most want in life [...] then you are on the right track (Ambriz, personal communication, 2019a).

1 Game of Thrones is the immensely popular television show that has aired for four seasons on HBO. The show is based on the epic fantasy novel series, A Song of Fire and Ice, written by George R. R. Martin. The first novel of the seven-book series is called A Game of Thrones; the show creators and HBO decided to keep that title as the overall name of the show (Cains, 2021). 


\section{Referencias}

Academy of Art University. (2019, January 28). What is Visual Development, Anyway? Academy of Art University. https://blog.academyart. edu/what-is-visual-development-anyway/\#. Xyh69C2z2CM

Ambriz, A. (2019a, April 4). Personal Interview (Jamie Carreón Interviewer) [Personal Interview].

Ambriz, A. (2019b, December 27) Personal Interview - Follow up (Jamie Carreón Interviewer) [Personal Interview].

Ambriz, A. (2020a, August 18). Personal Interview - Follow up (Jamie Carreón Interviewer) [Digital interview].

Ambriz, A. (2021a, March 29). Personal Interview - Follow up (Jamie Carreón Interviewer) [Digital interview].

Ambriz, R. (2021b, April 2). Personal interview Follow up (Jamie Carreón Interviewer) [Digital Interview].

Ángeles, E. (2013, June 24). Historia de la animación mexicana [Blog]. https://vinoglauco. wordpress.com/2013/06/24/historia-de-laanimacion-mexicana/

Anonymous (1944). Felix the Cat. Life Magazine [Online]. http://www.felixthecat.com/history.htm

Átomo Network. (2020, April 2). 107 facts of the Isle of Dogs by Wes Anderson [Youtube]. https:// www.youtube.com/watch?v=egEA77wSPRA

Betancourt, O. (2016). Cinema Fantasma, animación rifada hecha en México. Chilango [Online]. https://www.chilango.com/cine/cinemafantasma-animacion-rifada-hecha-en-mexico/

Britannica, T. Editors of Encyclopaedia. (2020, November 27), Jim Henson. Encyclopedia Britannica. https://www.britannica.com/ biography/Jim-Henson
Cains, J. (2021). What Is Game of Thrones? dummies a Wiley Brand. John Wiley \& Sons, Inc. /https://www.dummies.com/art-center/ performing-arts/filmmaking/what-is-game-ofthrones

Carreon, H. (August 15, 2020) Carreon Brothers Digital Interview (Jamie Carreón Interviewer) [Digital Interview].

Cartoon Network LA. (2019, November 11). Sustos ocultos de Frankelda | Cartoon Network [Youtube]. https://www.youtube.com/ watch?v=aY7GcKG-plk

Cervone, H. F. (2011). Understanding agile project management methods using SCRUM. OCLC Systems \& Services, 27(1), 18-22. https://doi. org/10.1108/10650751111106528

Cinema Fantasma. (2012, March). Pegaso de Hercules - Foto por Dan Parachutes. [Facebook]. https://www.facebook.com/ cinemafantasma/ photos/a.365804086792534/ 365804353459174

Cinema Fantasma. (2013a, February 22). Jabalito está aprendiendo a caminar. Qué bonito es el stop motion [Facebook]. https:// uww.facebook.com/cinemafantasma/ photos/530854473620827

Cinema Fantasma. (2013b, March 5). Felices porque llegó nuestro controlador Dragonframe. Animar va a ser mucho más fácil [Facebook]. https://www.facebook.com/cinemafantasma/ photos/535691799803761

Cinema Fantasma. (2014a, March 20). Cinema Fantasma en Alcázar del Castillo de Chapultepec con Adriana Rendón [Facebook]. https://www. facebook.com/cinemafantasma/photos/a.70866 9492505990/708670409172565/?type=3\&the ater

Cinema Fantasma. (2014b, September 14), iLo hicimos! ¡Logramos nuestra meta en Kickstarter! [Facebook]. https://www.facebook.com/ cinemafantasma/photos/a.272521102787500/7 98051973567741/?type=3\&theate 
Cinema Fantasma. (2015a, October 15). No sabemos quién fue pero alguien compró nuestro autómata. ¡Muchas gracias, comprador misterioso! [Facebook]. https://www.facebook.com/cinemafantasma/ photos/1004904812882455

Cinema Fantasma. (2015b, October 23). Preparándonos para Halloween [Instagram]. https://www.instagram. com/p/9ML5xEB-Gg/?utm_source=ig_web_copy_link

Cinema Fantasma. (2016, January 18). Jabalito tiene un nuevo hogar: Bleak House. Ojalá y no tenga pesadillas. Sabemos que el gran Guillermo Del Toro lo mantendrá sano y salvo entre tanta criatura extraña. Si quieren saber más sobre este lugar pueden ver este video de The Criterion Collection: http://youtu.be/ rOWXqEl846k [Facebook]. https://www.facebook.com/ cinemafantasma/photos/a.272521102787500/1373799 469326319/?type=3\&theater

Cinema Fantasma. (2017, February 23). The crew in the last shoot day of "In a drawer" of 19 Band of Horses [Facebook]. https://www.facebook.com/ cinemafantasma/photos/a.272521102787500/1373799 469326319/?type=3\&theater

Cinema Fantasma. (2018, November 23). Realizar nuestro primer largometraje, "La balada del fénix", es nuestro más grande sueño. Todas las horas invertidas valen la pena al ver a la Princesa Virian y a Arthos Fénix caminando en el bosque. Nuestro siguiente paso será competir en un mes en Ventana Sur en Argentina. iGracias a todos los que se han sumado a esta película medieval! — me siento lleno(a) de energía con Beto Petiches [Facebook]. https://www.facebook.com/ cinemafantasma/photos/a.272521102787500/2078327 995540126/?type=3\&theater

Cinema Fantasma. (2019a, November 12). No name [Facebook]. https://www.facebook.com/ cinemafantasma/photos/2678015365571383

Cinema Fantasma. (2019b, November 12). No name [Facebook]. https://www.facebook.com/ cinemafantasma/photos/2678113718894881

Cinema Fantasma. (2019c, November 12). No name [Facebook]. https://www.facebook.com/ cinemafantasma/photos/2678014652238121
Cinema Fantasma. (2019d, November 12). No name [Facebook]. https://www.facebook.com/ cinemafantasma/photos/2678014275571492

Cinema Fantasma. (2019). Today we had the honor to premiere the pilot for our horror stop-motion series at @pixelat!! Thanks to @cartoonnetworkla for this amazing opportunity! It is an anthology series narrated by our favorite ghost: Frankelda. Hope we can show you more soon! [Instagram]. https://www.instagram. com/p/B2DTJUUjDSg/?utm_source=ig_web_button_ share_sheet

Cinema Fantasma. (2020a). Instagram Stories - Process \#Frankelda [Instagram]. https://www.instagram.com/ stories/highlights/17960124838067475/

Cinema Fantasma. (2020b). Instagram Stories - Process [Instagram]. https://www.instagram.com/stories/ highlights/17960124838067475/

Cinema Fantasma. (2021a). +Projects. Cinema Fantasma. https://www.cinemafantasma.com/

Cinema Fantasma. (2021b). NFL - México. Cinema Fantasma. https://www.cinemafantasma.com/nflmexico

Cinema Fantasma. (2021c). Cinema Fantasma Edu. Cinema Fantasma. https://www.cinemafantasma.com/ edu

DragonFrame. (2020). What is Stop Motion Animation? Dragon Frame. www.dragonframe.com/introductionstop-motion-animation/

Dudok, A. (2021, May 3). Mexican Stop-Motion Series 'Frankelda's Book Of Spooks' is Coming To HBO Max. Cartoon Brew, LLC. https://www. cartoonbrew.com/series/mexican-stop-motionseries-frankeldas-book-of-spooks-is-coming-to-hbomax-204829.html?fbclid=IwAR3XDhJFt2_GfpXOv0_ Jt3tivpkDhwofWRicsmRq-1NhsJatSEK4d6BK9k0

Encyclopædia Britannica. (2021). Jim Henson and Kermit the Frog [Image]. Encyclopædia Britannica. https://www.britannica.com/topic/Kermit-the-Frog\#/ media/1/884156/239336 
Equihua, S. (2018). Jorge Gutierrez Biography. Design Journeys - AIGA. https://www.aiga.org/design-journeysjorge-gutierrez

FIDECINE. (2019). Resultados de la 2da. convocatoria fidecine 2019 para apoyo a producción y postproducción. FIDECINE-IMCINE. http://www.imcine. gob.mx/wp-content/uploads/2019/12/RESULTADOS-DELA-2DA.pdf

Film Affinity España (2020). Ana y Bruno. Filmaffinity - Movieaffinity. https://www.filmaffinity.com/es/ film549753.html

Forum México. (n.d.). Cinema Fantasma. Creando magia en el cine. H Grupo Editorial [Online]. https://www. forummexico.mx/arte/cinema-fantasma/

Garcia, M. (2016, November 21). Cinema Fantasma desarrolla "El cuento de un fénix", filme épico en stopmotion que supondrá su debut en largo. LatAm cinema. com. https://www.latamcinema.com/cinema-fantasmadesarrolla-el-cuento-de-un-fenix-filme-epico-en-stopmotion-que-supondra-su-debut-en-largo/

Gasek, T. (2012). Frame by Frame Stop Motion: NonTraditional Approaches to Stop Motion Animation. Routledge.

Grove, E. (2018, September 16). 4 Reasons Filmmakers attend Film Festivals. Raindance. https://www. raindance. org/4-reasons-filmmakers-attend-film-festivals/

Huerta, C. (2020, September 6) A través del stop motion, narran historias de terror. El Universal [Online]. https:// wrw.eluniversal.com.mx/espectaculos/traves-del-stopmotion-narran-historias-de-terror

Huntly, C. (2018, July 10). 5 ways to determine business success. Business 2 Community. https:// www.business2community.com/strategy/5-ways-todetermine-business-success-02091591

IMDb. (2005). Corpse Bride. IMDb.com, Inc. https://www. imdb.com/title/tt0121164/?ref_=tt_mv_close

IMDb. (2006) Anomalisa. IMDb.com, Inc. https://www. imdb.com/title/tt2401878/?ref_=tt_mv_close
IMDb. (2018a, May 11), Isle of Dogs. IMDb.com, Inc. https://www.imdb.com/title/tt5104604/?ref_=tt_mv_ close

IMDb. (2018b, November 30). The Ballad of the Phoenix. IMDb.com, Inc. https://www.imdb.com/title/ tt9362078/?ref_=ttmi_tt

IMDb. (2019). Adam Elliot. IMDb.com, Inc. https://www. imdb.com/name/nm0254178/

IMDb. (2021). Guillermo del Toro Biography. IMDb. com, Inc. https://www.imdb.com/name/nm0868219/ bio?ref_=nm_ov_bio_sm

Kredell, B., Loist, S., \& de Valck, M. (2016). Film Festivals : History, Theory, Method, Practice. Routledge.

López, A. (May 15, 2013). El día que Mickey Mouse fue presentado en sociedad (1928) [Blog]. 20 minutos. https://blogs.20minutos.es/yaestaellistoquetodolosabe/ tal-dia-como-hoy-de-1928-fue-presentado-en-sociedadmickey-mouse/

Lyons, S. (2012). Independent Film Producing : The Craft of Low Budget Filmmaking. Routledge.

MasterClass. (2020, November 8). Learn About the Postproduction Process in Film. MasterClass | Articles. https://www.masterclass.com/articles/learn-about-thepostproduction-process-in-film

Mcelwee, J. (2010). All This and Oswald Rabbit's Stew [Blog]. https://greenbriarpictureshows.blogspot. com/2010/04/all-this-and-oswald-rabbits-stew-i.html

Mutt and Jeff. (2014, December 27). In tvtropes Wikipedia. https://tvtropes.org/pmwiki/article_history. php?article=ComicStrip.MuttAndJeff

Núñez, L., \& Ocampo, M. V. (1996). El cine de animación en México [Bachelor 's Thesis] FES Aragón - UNAM. https://repositorio.unam.mx/contenidos/350465

Paramount Pictures. (2015, November 27). ANOMALISA - "Crafting Anomalisa" Featurette (2015) - Paramount Pictures [Youtube]. https://www.youtube. $\mathrm{com} /$ watch?v=Urzpw4WzUs4 
Purves, B. J. C. (2010). Basics Animation 04: Stop-motion. Bloomsbury.

Rios, J. (2020). Women We Love: Irene Melis - Cinema Fantasma. Girls at Film [Bolg]. https://girlsatfilms. com/2020/01/10/women-we-love-irene-melis-cinemafantasma/

Rodríguez, E. (2017, November 13). Solo 73\% de las empresas familiares cuentan con un plan de sucesión. El economista [Online]. https://www.eleconomista. com.mx/empresas/Solo-73-de-las-empresas-familiarescuentan-con-un-plan-de-sucesion-20171113-0023.html

Rodríguez, M. (2007). Animación: una perspectiva desde México ( $1^{a}$ ed.). UNAM - Centro Universitario de Estudios Cinematográficos.

Rowe, R. (2005). Bride stripped Bare. The Editors Guild Magazine, 26(4) [Online]. https://www. stopmotionworks.com/articles/cbrdstrpdbare. htm\#: : text=\%E2\%80\%9C\%20Most\%20 features $\% 2$ shoot $\% 2$ in $\% 2012$,shot $\% 20$ can $\% 20$ take\%20three\%20weeks

Sánchez, J. A. (2018, October 11). Fondeadora reta al sistema financiero con un nuevo banco. Grupo Milenio [Online]. https://www.milenio.com/negocios/ fondeadora-reta-al-sistema-financiero-con-un-nuevobanco

Santiago, F. (2017, July 23). Platino: la casa gana [Image]. El Norte | Gente. https://www.elnorte.com/ aplicacioneslibre/articulo/default.

Santillana (2021). About us. Santillana. https://www. santillana.com.mx/vivimos-la-educacion/

Sector Cine. (January 19, 2018). Un breve recorrido por el cine de animación en México. Televisa [Online]. https://www.sectorcine.com/noticias-nota/cual-es-lahistoria-de-la-animacion-en-elcine-mexicano/

Sliger, M. (2011). Agile project management with SCRUM. Paper presented at PMI® Global Congress 2011 North America, Dallas, TX. Newtown Square, PA: Project Management Institute. https://www.pmi.org/learning/ library/agile-project-management-scrum-6269
Staff Pixelatl. (2012). Qué es Pixelatl. Ideas | Definiciones. PIXELATL. https://pixelatl.com/es-MX/contenidos/ C9983F2F-94D9-11E6-B2FB-000D3A70A933/Que_es_ Pixelatl.html

Staff Rolling Stone Mexico. (2020, August 13). La animación en México. Rolling Stone [Online]. https:// www.rollingstone.com.mx/la-animacion-en-mexico/

Studio Ghibli. (2017, October). History of Studio Ghibli. Estudio Ghibli Inc. http://www.ghibli.jp/history/

studiobinder. (2020, March 15). What is Pre-Production in Film? A Blueprint for Success. StudioBinder Inc. https://www.studiobinder.com/blog/what-is-preproduction-definition/

@UniAsturias. (2021, March 3). Medición del éxito. No hay una sola manera de medir el éxito, existen muchos factores que lo acompañan y que forman parte de tu vida profesional y personal. \#Éxito \#Formación \#Coaching \#FelizMiércoles El 3 \#BuenosDías Hoy 3 \#Colombia [Twitter]. https://twitter.com/UniAsturias/ status/1367157950033313794/photo/1 